\title{
Categorial Hybrids in Kambaata ${ }^{1}$
}

Pre-publication version (15-03-2011). Article forthcoming in: Journal of African Languages and Linguistics

\section{YVONNE TREIS}

Abstract: The paper discusses three categorial hybrids in the East Cushitic language

Kambaata, viz. negative participles, agent adjectives and verbal nouns, all of which are shown to combine properties of two word classes (lexical categories) systematically. Unlike their affirmative counterparts, Kambaata negative relative verbs qualify as verbal adjectives (participles), because, apart from having verbal inflectional morphology and a completely verbal argument structure, they have also acquired adjectival morphology to indicate case/gender agreement with their head nouns. The combination of verbal and adjectival features is less balanced for agent adjectives, which retain fewer properties of the verbs they are based on; they are still able to govern objects and adverbial clauses, though. Kambaata verbal nouns behave almost entirely like verbs in relation to their dependents but as nouns in the clause they are arguments of. I argue that the negative participle formation and the verbal

1 Research for this paper was supported in part by grants from the German Research Foundation and by a La Trobe Post-doctoral Research Fellowship (2008-2011); this support is gratefully acknowledged. Revisions of this article were made during my time as a grantee of the program "Research in Paris" at the CNRS laboratory LLACAN (Langage, Langues et cultures d'Afrique noire). I am indebted to Tessema Handiso, Deginet Wotango, Philipos Paulos, Mathewos Shagana and all other Kambaata speakers that I have been working with in the past years. Thanks to two anonymous reviewers, Joachim Crass, Gerrit J. Dimmendaal, Birgit Hellwig, Gerd Jendraschek, Willem de Reuse and Joanne Taylor for helpful comments on an earlier version of this paper. All remaining shortcomings and errors are mine. 
noun formation are inflectional processes which change the word form word class from verb to adjective and verb to noun, respectively, but which preserve the properties of the lexeme word class (Verb). In contrast, the agent adjective formation is analysed as a derivational process with a greater impact on the lexeme word class.

\section{Introduction}

After word classes (parts of speech, lexical categories) have been established on the basis of morphological and syntactic criteria in a language, the language may turn out to have constructions which cannot clearly be categorised into one word class because they seem to be members of two word classes simultaneously. The most extensively discussed example of such a categorial hybrid (mixed category, morphosyntactic mismatch) is the English gerund (for a summary see, e.g., Malouf 2006). Like nouns, gerunds can be used as direct arguments of a verb (see the use of pressing as the subject in ex. (1)-(2)) and as complements of a preposition (see ex. (3)). In relation to their dependents, however, gerunds may exhibit nominal properties or verbal properties. The examples in (1)-(2), which have been found in two trains in Melbourne, illustrate that the gerund pressing can govern a direct object like a verb or a genitive phrase like a noun.

(1) Pressing this button will activate CCTV and emergency procedures.

(2) Pressing of this button will activate CCTV and emergency procedures.

(3) Pat is concerned about Sandy('s) getting arrested. (Malouf 2006: 176)

The past decades have seen a number of publications on categorial hybrids (Corbett 1987, Nikolaeva 2008, Spencer 2005, 2008, to name but a few). Whereas earlier publications were mainly concerned with gerunds, these works dealt with less studied hybrids, e.g. adjectival nouns and participles (verbal adjectives). 
In this paper, three categorial hybrids of Kambaata, an East Cushitic language of Ethiopia, are studied. ${ }^{2}$ The article is organised as follows. After an introduction into the defining features of the open word classes Noun, Verb and Adjective in Kambaata (section 2), I will argue in detail that negative relative verbs are almost perfect verb-adjective hybrids, with an adjectival external (morpho-)syntax and a verbal internal (morpho-)syntax (section 3). Therefore, this word form is most appropriately called a "negative participle," i.e. a negative verb form with adjectival features. ${ }^{3}$ The existence of negative participles has so far not yet been reported for any other Cushitic language.

In section 4, I will demonstrate that a second type of verbal adjective, so-called "agent adjectives", combines verbal and adjectival features in a less equally balanced way than negative participles. In section 5, Kambaata masdars (verbal nouns, gerunds) will be shown to behave like nouns phrase-externally but to retain most verbal properties in the clause that they are the head of. The term "gerund" is avoided in the following, because it is a term that is often used in the literature on Ethiopian languages in reference to converbs (e.g. in Wedekind 1990). Instead the term "masdar," a term used in the Arabic linguistic tradition for inflectional verbal nouns, will be preferred (in accordance with Haspelmath 1996).

In the conclusion (section 6), I will argue that the Kambaata negative participle and the masdar formations should best be considered inflectional processes, whereas the agent adjective formation is more of a derivational nature. Furthermore, the study of Kambaata categorial hybrids will provide support for Haspelmath's (1996) claim that inflectional word-

2 The Kambaata corpus used for this study consists of recorded texts, written texts and elicited material that was collected by the author between 2002 and 2007 in the Kambaata area in South Ethiopia.

3 This use of the term "participle" is in accordance with the typological literature; in some works on Cushitic languages, however, the terms "participle" or "participial" are used misleadingly in reference to non-finite or less-finite medial verb forms in adverbial function (e.g. in Owens 1985 and Hayward 1980), i.e. a verb form called "converb" in the typological literature (Haspelmath 1995, Azeb Amha and Dimmendaal 2006). 
class changing morphology tends to preserve the internal syntactic structure. The preservation of internal syntax will be shown to be a gradient parameter, according to which negative participle, masdar and agent adjective formations can be arranged on a continuum of decreasing impact on the syntactic structure of the base word class.

\section{Properties of open word classes}

Kambaata is a morphologically rich, strictly suffixing and rigorously head-final language. Four open word classes can be defined on the basis of morphological and syntactic features: nouns, verbs, adjectives ${ }^{4}$ and ideophones. The last category will not concern us here. Nouns are prototypically used as referring units and in this function they occur as heads of NPs. As the head of an NP, a noun can govern modifiers, i.e. adjectives, demonstratives, numerals and relative clauses, which generally precede the head noun. Apart from expressing arguments of a predicate, nouns can function as predicates themselves (in combination with a copula) and be used as adverbials. Kambaata nouns are obligatorily specified for case and gender. They are categorised into 21 declensions, depending on the shape of their accusative form; see, for instance, the -ú-declension (M3) in (4). Case is marked by segmental suffixes (e.g. - $\mathbf{u}$ in the accusative and nominative and $\mathbf{- i}$ in the genitive of declension M3) and by a characteristic stress pattern; in some declensions, e.g. M3, masculine accusative and nominative forms are differentiated by stress alone. ${ }^{6}$

4 The word class of adjectives can be assumed to constitute a sub-class of a word class of attributes. Apart from adjectives, the word class of attributes contains two other case- and gender-agreeing sub-classes, namely numerals and demonstratives (Treis 2008a: 81-97).

5 There are 12 masculine and 9 feminine nominal declensions in Kambaata; M3, e.g., is the $3^{\text {rd }}$ masculine declension (Treis 2008a: 103).

6 The following abbreviations are used: $1 / 2$ / 3 first / second / third person, AA agent adjective, ABL ablative, ACC accusative, CAUS causative, COND conditional clause, COP1 locative copula, COP2 ascriptive copula, COP3 
(4)

$\begin{array}{lll}\text { ACC } & \text { yabur-ú } & \text { 'lip(s)' } \\ \text { NOM } & \text { yabúr-u } & \text { 'lip(s)' } \\ \text { GEN } & \text { yabur-í } & \text { 'of (a) lip(s)' } \\ \text { DAT } & \text { yabur-íi } & \text { 'for (a) lip(s)' } \\ \text { ABL } & \text { yabur-íichch } & \text { 'from (a) lip(s)' } \\ \text { ICP } & \text { yabur-íin } & \text { 'with (a) lip(s)' } \\ \text { LOC } & \text { yabur-óon } & \text { 'on (a) lip(s)' } \\ \text { OBL } & \text { yabúr-o } & \text { 'on (a) lip(s) / lip'7 }\end{array}$

Most feminine nouns receive an additional morpheme -ta, some masculine nouns an (optional) additional morpheme -ha in the accusative case, which is also the citation form; consider ex. (5)-(6). For ease of identification, the first inflectional morpheme after the

identificational copula, CRD1 coordination (final vowel lengthening), CRD2 coordination with -na, DAT dative, DS different subject, F feminine, GEN genitive, HON honorific/impersonal, ICO imperfective converb, ICP instrumental-comitative-perlative, IDEM demonstrative pronoun: proximal, IMP imperative, INACT past tense, counterfactual (“inactual”), IPV imperfective, LOC locative, M masculine, MID middle voice, N pragmatically conditioned undetermined morpheme, NCO negative converb, NEG negation, NMZ1 nominalisation operation 1, NMZ2 nominalisation operation 2, NMZPL plural nominaliser, NOM nominative, NREL negative relative, negative participle, OBJ object, OBL oblique case, PASS passive, PCO perfective converb, PL plural / plurative, POSS possessive, PRED predicate form, PROG progressive, PROP proprietive derivation, PVE e-perfective, PVO operfective, Q question, REL relativisation, SG singular / singulative, SIM similative, adverbialiser, VOC vocative, vV vowel lengthening.

7 The Kambaata data in this paper are written in the official orthography (Maatewoos Shagana 1992). The following graphemes are not in accordance with the IPA conventions: $\left\langle\mathrm{ph}>=/ \mathrm{p}^{\mathrm{\prime}} /,\langle\mathrm{x}\rangle=\right| \mathrm{t}^{\prime} /,\langle\mathrm{q}\rangle=/ \mathrm{k}^{\prime} /,\langle\mathrm{j}\rangle$ $=/ \mathrm{d} 3 /,<\mathrm{c}>=/ \mathrm{t} \mathrm{f} /,<\mathrm{ch}>=/ \mathrm{t} \mathrm{f} /,<\mathrm{sh}>=/ \mathrm{J} /,<\mathrm{y}>=/ \mathrm{j} /$ and $<^{\prime}>=/ 2 /$. Length is indicated by double letters, e.g. $<\mathrm{aa}>=/ \mathrm{a}: /,<\mathrm{bb}>=/ \mathrm{b}: /$, and $<\mathrm{shsh}>=/ \int: /$. Due to an idiosyncratic convention, the second consonant of a glottal stop-sonorant cluster is generally written as double, although the cluster only consists of two phonemes, e.g. $<$ 'mm $>=/ 2 \mathrm{~m} /$. Nasalisation is marked by a macron, e.g. $<\overline{\mathbf{a}}>=/ \tilde{a} /$. Word-final unstressed $\mathbf{i}$ does not occur orthographically, irrespective of its phonological status. 
nominal stem is henceforth called the "primary case/gender morpheme", the subsequent morpheme (e.g. -ta) is called the "secondary case/gender morpheme".

(5) Masculine: adab-áa(-ha) 'boy', boor-á 'ox', woqq-áa(-ha) 'road', qophphan-á 'lie'

(6) Feminine: mesel-ée-ta 'girl', sulum-ú-ta 'heifer', uull-á-ta 'land', gar-í-ta 'truth'

Modifying nouns are genitive-marked and do not agree with the head noun, as seen in ex. (7).

$$
\begin{array}{ll}
\text { gur-áta (F.ACC) } & \text { 'left (side)' } \\
\text { gur-á (F.GEN) gennan-ú (M.ACC) } & \text { 'left shoulder' (lit.: "shoulder of the left side") } \\
\text { gur-á (F.GEN) ang-á-ta (F.ACC) } & \text { 'left hand' (lit.: "hand of the left side") }
\end{array}
$$

Kambaata verbs inflect for aspect (imperfective, e-/o-perfective and progressive), mood (indicative, imperative-jussive, and preventive), subordination (main vs. subordinate verb), polarity (affirmative vs. negative) as well as subject agreement (person, gender, number, and social status of the subject are indicated by portmanteau morphemes on the verb). Kambaata verbs can be arranged on a scale of decreasing finiteness, that is decreasing inflectional possibilities. Verbs in main clauses have the full range of inflectional possibilities; they are fully finite and, in principle, the only verb forms that can complete a sentence. The structure of an indicative affirmative main verb is outlined in Table 1: the verbal stem is followed by inflectional morphemes (between double bars) and, optionally, by an object suffix.

Table 1. Structure of indicative affirmative main verbs

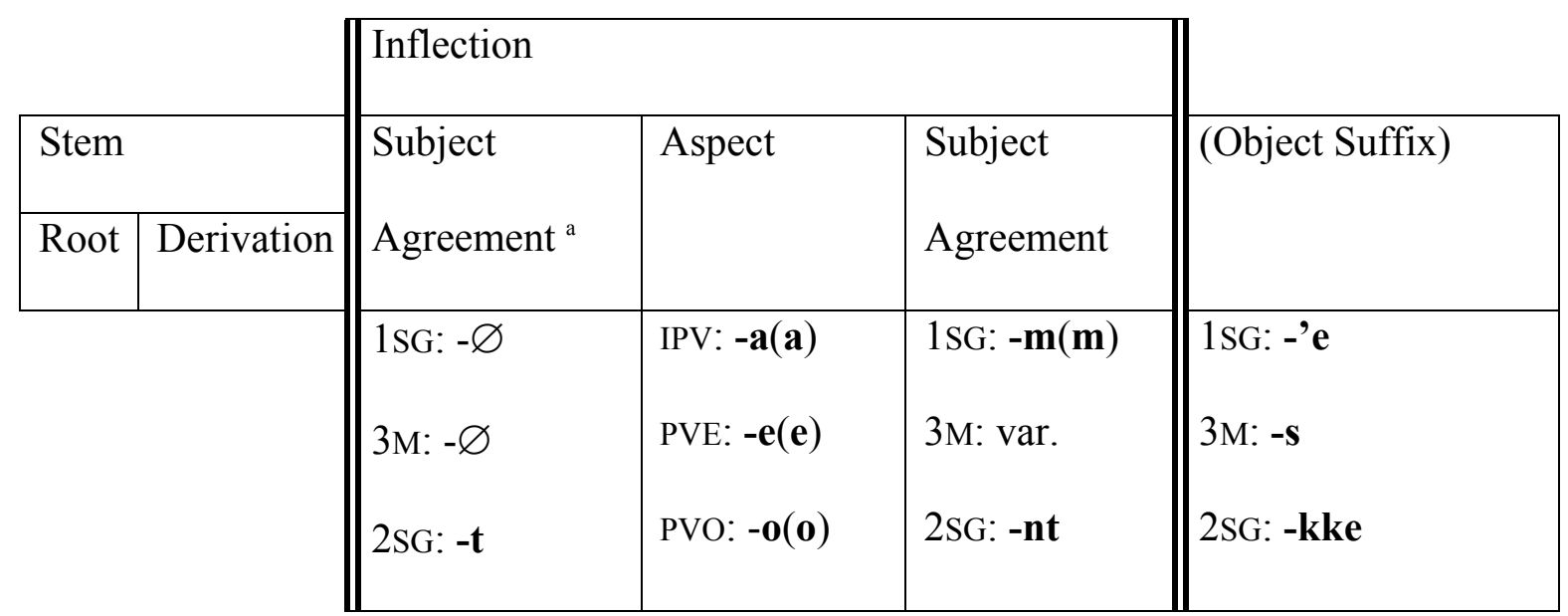




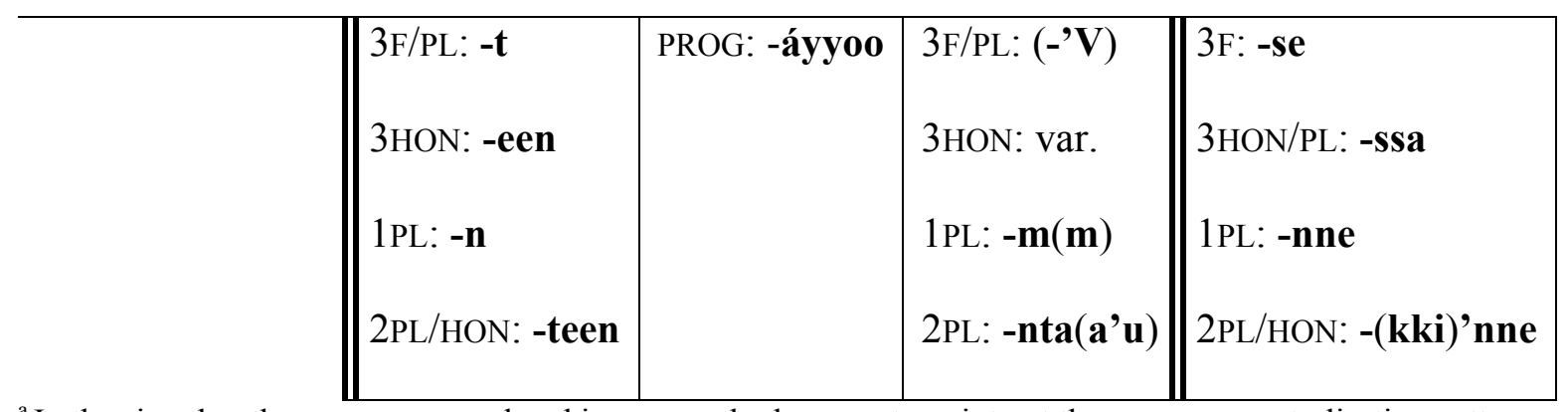

${ }^{\mathrm{a}}$ In the singular, the persons are ordered in an unorthodox way to point out the common neutralisation pattern $1 \mathrm{SG}=3 \mathrm{M}$ and $2 \mathrm{SG}=3 \mathrm{~F} / \mathrm{PL}$.

Compared to main clause verbs, co-subordinate verbs such as converbs (non-final verb forms in adverbial function) have a reduced number of aspects (only perfective vs. imperfective) and person values (only 1SG/3M, 2SG/3F/3PL, 3HON, 1PL and 2PL); they cannot be marked for mood. Converbs usually require a superordinate main verb or a copula and are considered less finite, though not entirely non-finite.

The existence of adjectives is disputed for some Cushitic languages (Banti 1986). However, it only makes sense to argue in this paper that Kambaata has verb-adjective hybrids if the language can be shown to have a word class Adjective distinct from the word classes of Verb and Noun. The arguments put forward in Treis (2008a) are summarised in the following. Adjectives are prototypically used as modifiers of a head noun in an NP. As such, they agree with the head noun in case and gender; consider ex. (8)-(10). Modifying adjectives distinguish two genders, i.e. masculine and feminine, and three cases, i.e. nominative, accusative and oblique (Table 2). The oblique case signals agreement with head nouns that are neither nominative nor accusative; see the oblique adjectives in front of ablative nouns in ex. (10).

$$
\begin{aligned}
& \text { muccur-ú-ta (F.ACC) xenq-ú-ta } \quad \text { (F.ACC) 'clean mug' } \\
& \text { muccur-ú (M.ACC) oroob-ú } \quad \text { (M.ACC) 'clean milking vessel' }
\end{aligned}
$$

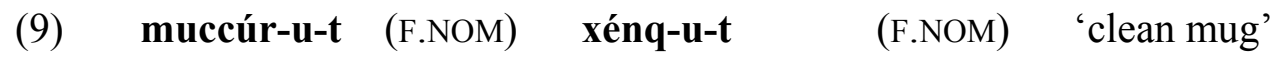

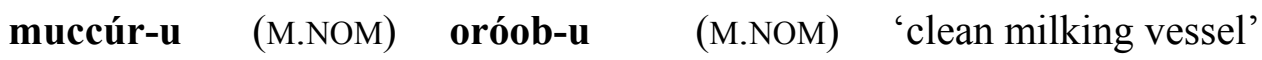

$$
\begin{aligned}
& \text { (10) muccúr-o (F.OBL) xenq-óochch (F.ABL) 'from the clean mug' }
\end{aligned}
$$


muccúr-o (M.OBL) oroob-íichch (M.ABL) 'from the clean milking vessel'

Table 2. Case and gender paradigm of adjectives in -ú(-ta) (Declension A2)

\begin{tabular}{|l|l|l|l|}
\cline { 2 - 4 } \multicolumn{1}{c|}{} & ACC & NOM & OBL \\
\hline M & -ú & '-u & '-o $\sim$ '-u-a \\
\hline F & -ú-ta & '-ut & '-o $\sim$ '-u-ta \\
\hline
\end{tabular}

Apart from this unique agreement potential, there are some features that adjectives share with nouns and verbs. Like nouns, adjectives can function as heads of an NP without further measures being taken: it is not necessary to nominalise them or to insert a dummy head (such as English one). As NP heads, they distinguish as many case forms as nouns, namely eight cases. According to the shape of the citation form, adjectives are categorised into the respective nominal declensions and then inflect like nouns. Adjectives of declension A2 -ú / -ú-ta, for instance, inflect like nouns of declension M3 in -ú and F3a in -ú-ta.

Table 3. Adjectives inflecting as NP-heads: the example of an adjective in -ú(-ta)

\begin{tabular}{|l|l|l|l|l|l|l|l|}
\cline { 2 - 7 } \multicolumn{1}{l|}{} & ACC & NOM & GEN & DAT & ABL & ICP & LOC \\
\hline M & -ú & -u & -í & -íi(-ha) & -íichch & -íin & -óon \\
\hline F & -ú-ta & -u-t & -ó & -óo(-ha) & -óochch & -óon & -óon \\
\hline
\end{tabular}

The adjective hiilíin 'with the bad (one)' occurs in the instrumental-comitative-perlative case in ex. (11).
(11) hiil-íin hoshsh-óo(-hu)
hāy-înn
kad-áno

bad-M.ICP pass_the_day-3M.PVO.REL.NMZ1-M.NOM front_leg-M.ICP kick-3M.IPV

'The one who has passed the day with a bad (one) will kick with the front legs.' (Proverb) 
Like verbs, adjectives are modified by degree adverbials. Furthermore, adjectives are able to govern accusative and dative complements, expressing with respect to what something has a certain quality. Sentence (12) exemplifies how the modifying adjective qáarat 'strong' governs the accusative complement qoxxú 'eating'.
qoxx-ú qáar-at cíil-l-at
moos-íichch ka'mm-an-táa'u
eat-M.ACC strong-F.NOM child-PL-F.NOM disease-M.ABL protect.MID-PASS-3F.IPV
'Children that eat heartily (lit.: "are strong (with respect to) eating") are protected against diseases.'

In contrast to adjectives (13), nouns cannot govern complements (14); nouns can only be modified, even if they are derived from adjectives; see lungimáta 'weakness' in ex. (14).
(13) nig-á
lung-á
muscle-M.ACC weak-M.ACC
'weak with respect to the muscles'
(14) nig-í
(*nig-á)
lung-im-áta
muscle-M.GEN muscle-M.ACC weak-QUALITY-F.ACC
'muscle weakness'

To summarise, adjectives cannot be subsumed under the word classes of nouns or verbs. Although they share certain properties with nouns and verbs, it is their unique agreement morphology which sets them apart from other word classes and which defines adjectives as a separate word class in Kambaata.

\section{Negative participles}

In the following section, it is argued that negative relative verbs are verb-adjective hybrids (participles). Before discussing their nature, a general introduction into relativisation is given. 


\subsection{The basic mechanisms of relativisation}

Relative clauses, irrespective of their length, are positioned to the left of the noun they modify. The relative verb is always the last constituent in the relative clause and thus immediately precedes the modified noun. Only indicative main verbs may constitute the head of a relative clause. There are no relative pronouns, enclitics or affixes in Kambaata. Relative verbs are primarily marked suprasegmentally, namely by word-final stress, as the paradigms of the imperfective and the o-perfective verbs in Table 4 illustrate. ${ }^{8}$ Note that in the main verb column, stress is located on a non-final syllable, whereas in the relative verb column it is always the rightmost syllable that is stressed (the vowels of stressed syllables are underlined). The shift of stress from a non-final to the final syllable triggers voicing of formerly unstressed and devoiced verb-final vowels, e.g. xuundáamm/i/ 'we will see' and xuundaammí 'which we will see'. Unstressed and devoiced final $\mathbf{i}$ is generally not written in the Kambaata orthography. All Kambaata words ending in a consonant orthographically do actually end in an unstressed and devoiced $\mathbf{i}$, which is voiced as soon as another morpheme is added or as soon as stress settles on it.

Apart from suprasegmental differences, there are also minor segmental dissimilarities between main and relative verbs, among them the elision of sub-morphemic elements, e.g. kul-téenta(a'u) 2PL.PVO 'you told' and kul-teentá(a) 'which you told' (for details see Treis 2008b).

Table 4. Inflectional suffixes of two main verb paradigms and their respective relative verb paradigms

8 In contrast to what has been assumed in Treis (2008b), progressive verbs and some forms of the e-perfective paradigm do not seem to undergo stress shift and the relative forms seem to be indistinguishable from the main verb forms. This phenomenon requires further investigation. 


\begin{tabular}{|c|c|c|c|}
\hline & & Main verb form & Relative verb form \\
\hline $1 \mathrm{SG}^{\mathrm{a}}$ & $\begin{array}{l}\text { IPV } \\
\text { PVO }\end{array}$ & 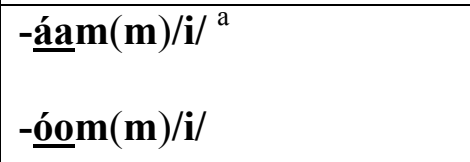 & $\begin{array}{l}\text {-aammí } \\
\text {-oommí }^{c}\end{array}$ \\
\hline $3 \mathrm{M}$ & $\begin{array}{l}\text { IPV } \\
\text { PVO }\end{array}$ & $\begin{array}{l}\text {-áno } \\
\text {--o }\end{array}$ & $\begin{array}{l}\text {-anó } \\
\text { - } \underline{\text { ó }}\end{array}$ \\
\hline $2 \mathrm{SG}$ & $\begin{array}{l}\text { IPV } \\
\text { PVO }\end{array}$ & $\begin{array}{l}\text {-táant/i/ } \\
\text {-tóont/i/ }\end{array}$ & $\begin{array}{l}\text {-taantí } \\
\text {-toontí }\end{array}$ \\
\hline $3 \mathrm{~F} / \mathrm{PL}$ & $\begin{array}{l}\text { IPV } \\
\text { PVO }\end{array}$ & 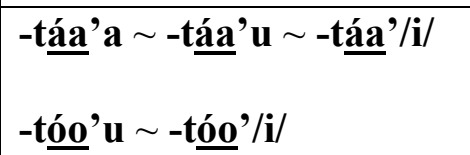 & $\begin{array}{l}\text {-táa }^{\mathrm{d}} \\
\text {-tóo }^{\mathrm{d}}\end{array}$ \\
\hline $3 \mathrm{HON}$ & $\begin{array}{l}\text { IPV } \\
\text { PVO }\end{array}$ & $\begin{array}{l}\text {-éenno } \\
\text {-éemma }\left(\mathbf{a}^{\prime} \mathbf{u} \sim \mathbf{a}^{\prime} \mathbf{a} \sim \mathbf{a}^{\prime} / \mathbf{i} /\right)\end{array}$ & $\begin{array}{l}\text {-eennó } \\
\text {-eemmáa }(\mathbf{a})^{\mathrm{d}}\end{array}$ \\
\hline $1 \mathrm{PL}$ & $\begin{array}{l}\text { IPV } \\
\text { PVO }\end{array}$ & $\begin{array}{l}\text {-náam }(\mathbf{m}) / \mathbf{i} / \\
-n \underline{o ́ o m}(\mathbf{m}) / \mathbf{i} /\end{array}$ & $\begin{array}{l}- \text { naammí } \\
- \text { noommí }\end{array}$ \\
\hline $2 \mathrm{PL} / \mathrm{HON}$ & $\begin{array}{l}\text { IPV } \\
\text { PVO }\end{array}$ & $\begin{array}{l}\text {-teenánta } \\
\text {-téenta }\left(\mathbf{a}^{\prime} \mathbf{u} \sim \mathbf{a}^{\prime} \mathbf{a} \sim \mathbf{a}^{\prime} / \mathbf{i} /\right)\end{array}$ & $\begin{array}{l}\operatorname{-teenantá} \\
-\operatorname{teentá}(\underline{a})^{\mathrm{d}}\end{array}$ \\
\hline
\end{tabular}

${ }^{\mathrm{a}}$ According to the Kambaata orthographic conventions, unstressed devoiced final $\mathbf{i}$ is not written. However, they have been added between /brackets/ in this table so that the stress shift is here more clearly visible to readers.

${ }^{\mathrm{b}}$ In the singular, the verb forms of all paradigms are in the unusual order $1 \mathrm{SG}-3 \mathrm{M}-2 \mathrm{SG}-3 \mathrm{~F} / \mathrm{PL}$ so that readers can easily see which verbal paradigms display the common neutralisation pattern $1 \mathrm{SG}=3 \mathrm{M}$ and $2 \mathrm{SG}=3 \mathrm{~F} / \mathrm{PL}$.

${ }^{\mathrm{c}}$ The relative form must be realised with a geminate $\mathbf{m m}$.

d The glottal elements ' $\mathbf{V}$ is deleted before relativisation.

Ex. (15) and (16) contrast main verb forms and noun-modifying relative verb forms. The verb in ex. (16) is extended by an object pronoun, which constitutes the rightmost syllable onto which stress moves when the verb is relativised. The square brackets indicate the boundaries of the relative clauses and the NP they are part of. 
(15)

(a) hagás hagág y-áano

ibis.M.NOM strut_about say-3M.IPV

'The ibis struts about.'

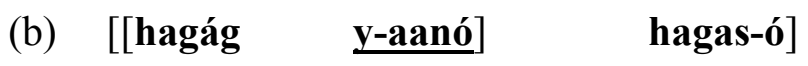

strut_about say-3M.IPV.REL ibis-M.ACC

'the ibis which struts about'

(16)

(a) léh-u bírr-u yóo-’e

six-M.NOM birr-M.NOM COP1.3-1SG.OBJ

'I have six birrs.' (lit.: “Six birrs are to me.”)9

(b) [[yoo-'é $] \quad$ leh-ú birr-á $]$

COP1.3-1SG.OBJ.REL six-M.ACC birr-M.ACC

'the six birrs that I have' (lit.: "the six birrs that are to me")

A relative clause and a head noun constitute a complex NP whose syntactic function is indicated by the case morpheme on the head noun; see birríichch in ex. (17).

\begin{tabular}{|c|c|c|c|}
\hline [[yoo-'é $]$ & léh-o & birr-íichch] ónt-o & manch-íi \\
\hline COP1.3-1SG.OBJ & REL six-M.OBL & birr-M.ABL five-M.OBL $\quad r$ & $\operatorname{man}(. S G)-M . D A T$ \\
\hline mám-mat-ú & birr-á & beekk-oommíichch esáa & mát-u \\
\hline one-one-M.ACC & birr-M.ACC & share-1SG.PVO.ABL 1SG.DAT & one-M.NOM \\
\hline \multicolumn{4}{|l|}{ fa'-áno-’e } \\
\hline \multicolumn{4}{|c|}{ remain-3M.IPV-1SG.OBJ } \\
\hline
\end{tabular}

Kambaata covers all positions on the Keenan and Comrie (1977) NP accessibility hierarchy: subject $>$ direct object $>$ indirect object $>$ oblique $>$ possessor. NPs of any function in the

$9 \quad$ Birr $=$ Ethiopian currency 
relative clause can be relativised upon; see the discussion in Treis (2008b). Kambaata predominantly applies the gap strategy in relative clause formation. There is no indication of the syntactic function or the semantic role of the head noun in the relative clause; the function or semantic role has to be inferred from the linguistic and extra-linguistic context. ${ }^{10}$ In ex. (15)-(17), the head noun is most naturally interpreted as the subject of the relative verb but in ex. (18) it is interpreted as a temporal adjunct.
(18) [[qal-amm-ó $]$
sakkí wogg-áan]
give_birth-PASS-3M.PVO.REL third year-M.LOC
'three years after his birth' (lit.: "in the third year in which he had been born”) (Kambaatissata 8: 20) $)^{11}$

The head noun does not always have to be interpreted as an argument or adjunct of the relative clause itself; in ex. (19), odáas is interpreted as the direct object of the converb clause that is co-subordinate to the relative clause, i.e. as the object of tákk a'í but not of fulló.

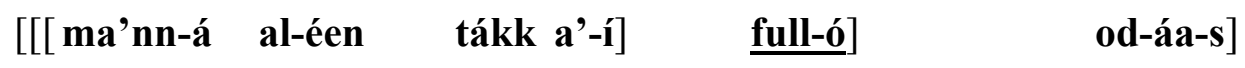

bed-F.GEN top-M.LOC drop do-3M.PCO go_out-3M.PVO.REL stuff-F.ACC-3M.POSS

$$
\text { xább a'-í afuushsh-í ful-áni-yan (...) }
$$

properly do-3M.PCO put-3M.PCO go_out-3M.ICO-DS

'(...) he put the stuff which he had dropped on his bed (before) going out on their proper place and went out (again) (...).' (lit.: 'the stuff which he had dropped and went out") (Kambaatissata 8: 21)

\footnotetext{
10 Exception: If the head noun functions as a possessor, a resumptive possessive pronoun is used on the possessed NP in the relative clause.

11 Data from Kambaatissata (1989) have been segmented, glossed, and translated; stress marking has been added.
} 
Furthermore, Kambaata does not distinguish between relative clauses and noun-complement clauses. Or put differently, it is not even necessary that the head noun has a function at all in the relative clause (or a clause dependent on the relative clause). ${ }^{12}$ The head noun tassóo 'hope' in ex. (20) denotes the proposition given in the preceding modifying clauses but it does not have a function in the coordinate relative clauses.

$\begin{array}{clc}{[[\text { mat-é }} & \mathbf{a m - a ́}-\mathbf{s} & \underline{\text { xuud-anó-na }} \\ \text { one-TIMES } & \text { mother-F.ACC-3M.POSS } & \text { see-3M.IPV.REL-CRD2 }\end{array}$

\section{daqq-am-anó}

$$
\text { tass-óo] }
$$

find.MID-PASS-3M.IPV.REL hope-M.NOM

'The hope of seeing and meeting his mother once (again) (...).' /

'The hope that he would see and meet his mother once (again) (...).' (Kambaatissata 8: 22)

For the following discussion it is important to keep in mind that affirmative relative verbs have an overall verbal morphology and that there are no traces of case and gender agreement with the modified noun.

\subsection{The negation of main clause verbs and relative verbs compared}

While affirmative main clause verbs and their corresponding relative forms are segmentally (though not suprasegmentally) alike, negative main clause verbs and their corresponding relative forms differ considerably. Before dealing in detail with the negation of relative clauses, it is necessary to give a short overview of main verb negation. Negative main verbs are characterised by an additional -ba('a)-morpheme. ${ }^{13}$ For the formation of negative

12 The relative clauses in Kambaata are thus functionally equivalent to "noun-modifying clauses" in various Asian languages (see Comrie 1998).

13 Kambaata has several other formally unrelated negative morphemes: -ka for jussive verbs, -oot for imperatives and -u'nna for converbs; for details see Treis (forthcoming b). 
imperfective main verbs, -ba('a) is added after the imperfective morpheme (see (21)-(b)) and the object pronoun (see (21)-(d)). The negative morpheme has no influence on the stress pattern, nor does it lead to a reduction of person distinctions (Table 5).
(a) hab-áno 'he forgets / will forget'
(b) hab-áno-ba'a 'he does / will not forget'
(c) hab-áno-ssa 'he forgets / will forget them'
(d) hab-áno-ssa-ba'a 'he does / will not forget them'

Table 5. Imperfective main verb paradigms: affirmative and negative compared

\begin{tabular}{|l|l|l|}
\cline { 2 - 3 } \multicolumn{1}{l|}{} & Affirmative & Negative \\
\hline $1 \mathrm{SG}$ & -Ø-áam(m) & -Ø-áam-ba('a) \\
\hline $3 \mathrm{M}$ & -Ø-áno & -Ø-áno-ba('a) \\
\hline 2SG & -t-áant & -t-áanti-ba('a) \\
\hline 3F/PL & -t-áa'a $\sim$-t-áa'u $\sim$-t-áa'a' & -t-áa-ba('a) \\
\hline 3HON & -éen-no & -éen-no-ba('a) \\
\hline 1PL & -n-áam(m) & -n-áam-ba('a) \\
\hline 2PL/HON & -teen-ánta(a'u $\sim \mathbf{a}$ 'a $\sim \mathbf{a} ')$ & -teen-ánta-ba('a) \\
\hline
\end{tabular}

The remaining three indicative main verb paradigms, i.e. the two perfective paradigms ${ }^{14}$ and the progressive paradigm, share one negative paradigm (Table 6). This so-called "nonimperfective" negative paradigm also contains the negative morpheme -ba('a), which we have already seen to be part of the imperfective negative paradigm in Table 5 above. The nonimperfective negative paradigm is furthermore characterised by an enigmatic morpheme -im

14 The functional differences between the e- and o-perfective forms require further investigation. 
and a reduction of person distinctions from seven in the affirmative to five in the negative. The negative morpheme is stressed.

Table 6. Non-imperfective main verb paradigms

\begin{tabular}{|c|c|c|c|c|}
\hline & \multicolumn{3}{|l|}{ Affirmative } & \multirow{2}{*}{ Negative } \\
\hline & e-Perfective ${ }^{b}$ & o-Perfective & Progressive & \\
\hline $1 \mathrm{SG}$ & $-\varnothing-\operatorname{eem}(\mathrm{m})^{\mathrm{a}}$ & -Ø-óom $(\mathbf{m})^{\mathrm{a}}$ & -Ø-áyyoom(m) & \multirow[t]{2}{*}{-Ø-im-bá('a) } \\
\hline $3 \mathrm{M}$ & $\begin{array}{l}\text {-Ø-ее’u } \\
\sim^{-e e^{a}}\end{array}$ & $-\varnothing-0^{a}$ & $\begin{array}{l}\text {-Ø-áyуоo’u } \\
\text { Ø-áyуоo' }\end{array}$ & \\
\hline $2 \mathrm{SG}$ & -t-eent & -t-óont & -t-áyyoont & \multirow[t]{2}{*}{-t-ím-bá('a) } \\
\hline $3 \mathrm{~F} / \mathrm{PL}$ & $\begin{array}{l}\text {-t-ee'u } \\
\sim \text {-t-ee' }\end{array}$ & $\begin{array}{l}\text {-t-óo’u } \\
\sim \text {-tóo’ }\end{array}$ & $\begin{array}{l}\text {-t-áyyoo’u } \\
\sim \text { t-áyyoo' }\end{array}$ & \\
\hline $3 \mathrm{HON}$ & \multicolumn{2}{|c|}{-éem-ma( $\left.\mathbf{a}^{\prime} \mathbf{u} \sim \mathbf{a}^{\prime} \mathbf{a} \sim \mathbf{a}^{\prime}\right)$} & -een-áyyoo’u & -een-im-bá('a) \\
\hline $1 \mathrm{PL}$ & -n-eem $(m)$ & -n-óom(m) & -n-áyyoom(m) & -n-im-bá('a) \\
\hline $2 \mathrm{PL} / \mathrm{HON}$ & \multicolumn{2}{|c|}{-tée-nta(a'u $\sim$ a'a $\sim$ a') } & -teen-áyyoonta $\left(\mathbf{a}^{\prime} \mathbf{u} \sim \mathbf{a}^{\prime} \mathbf{a} \sim \mathbf{a}^{\prime}\right)$ & -teen-im-bá('a) \\
\hline
\end{tabular}

${ }^{\mathrm{a}}$ The preceding stem-final consonant undergoes palatalisation and gemination.

${ }^{\mathrm{b}}$ If a suffix is unmarked for stress in this column, the stress location is dependent on the structure of the preceding verbal stem.

The object pronoun is added after the negative morpheme (compare ex. (21)-(d) and (22)-(d)) and triggers the loss of the "glottal element" ' $a$.
(22)
(a) hább-o
'he forgot'
(b) hab-im-bá'a
'he did not forget'
(c) hább-o-ssa
'he forgot them'
(d) hab-im-bá-ssa
'he did not forget them' 
Unlike in the domain of positive polarity (see ex. (23)-(a) and (b)), it is not possible to generate a negative relative verb simply by having a negative main verb (as in ex. (23)-(c)) undergo a stress shift; consider the ill-formed verbs in ex. (23)-(d) and (e). ${ }^{15}$

(a) hab-áno

(b) hab-anó

(c) hab-áno-ba'a

(d) *hab-ano-ba’á

(e) *hab-ano-ba' $\mathbf{i}^{16}$ 'he forgets / will forget'

'which (he) forgets / will forget'

'he does / will not forget'

(intended meaning:) 'which (he) does / will not forget'

(intended meaning:) 'which (he) does / will not forget'

Instead, relative verbs are marked as negative by the morpheme -umb, as shown in Table 7. Only five forms are distinguished in this paradigm, because the difference between 1SG and $3 \mathrm{M}$ as well as $2 \mathrm{SG}$ and $3 \mathrm{~F} / \mathrm{PL}$ is neutralised. The morphemes preceding -umb are the subject agreement morphemes (also found in the second column of Table 1). The function of the final -ú will be explained further below. One could segment -umb further into -um-b and thus point out the formal resemblance to the morpheme sequence -im-bá('a) of non-imperfective negative main verbs (Table 6).

15 Here only imperfective examples are given. Note, however, that relative forms can neither be derived by stress shift from negative non-imperfective main verbs (Table 6).

16 The verb form with a final -í was checked because negative relative verbs in the closely related language Qabeena end in -ba'i (Crass 2005: 287). 
Table 7. Negative participles (relative verbs)

\begin{tabular}{|c|c|}
\hline & Negative \\
\hline $1 \mathrm{SG}$ & \multirow{2}{*}{-Ø-umb-ú } \\
\hline $3 \mathrm{M}$ & \\
\hline $2 \mathrm{SG}$ & \multirow{2}{*}{-t-umb-ú } \\
\hline $3 \mathrm{~F} / \mathrm{PL}$ & \\
\hline $3 \mathrm{HON}$ & -een-umb-ú \\
\hline $1 \mathrm{PL}$ & -n-umb-ú \\
\hline $2 \mathrm{PL} / \mathrm{HON}$ & -teen-umb-ú \\
\hline
\end{tabular}

Ex. (24) illustrates the use of a negative relative verb. The noun wéeshshu is the subject of the main clause; it is modified by a negative relative clause, which has zíi'ru as its subject.

(24) [[zíi’r-u

type_of_vermin-M.NOM pierce-3M.NREL-M.NOM enset(.SG)-M.NOM wéeshsh-u] hór-unku meco'-áam-u-a

all-M.NOM $<$ N $>$ leaf_sheath-PROP-M.PRED-M.COP2

'All enset plants that are not affected by the ziir'a-vermin develop (thick) leaf sheaths.'

Negative relative verbs of the above type can be generated for all verbs of the language, apart from the locative verbal copula yoo- (COP1). The copula is incompatible with the negative relative morpheme -umb. Instead, it is marked as relative by a stress shift both in the affirmative and negative paradigm; see the negative relative form in ex. (25). ${ }^{17}$

17 It cannot yet be explained why the final a of the negative morpheme changes to i; see yóo-ba'a $\rightarrow$ REL yooba'í. Note that all negative relative verbs in Qabeena (Crass 2005: 87) and Alaaba (Schneider-Blum 2007: 252) are marked by -ba'i; a morpheme -umb is not attested in these languages. 
disease-M.NOM COP1.3-NEG.REL-CRD2 spend_time-3F.PVE.REL land-F.LOC '(...) on (a plot of) land which is free of (bacterial wilt) disease and which was not farmed (lit.: "which has spent time") (before). (Kambaatissata 8: 32)

\subsection{Verbal and adjectival properties of negative participles}

Negative relative verbs are verb-adjective hybrids and, therefore, called negative participles. ${ }^{18}$ Their verbal and adjectival properties are evaluated in detail in the following section.

\subsubsection{Agreement}

The strongest evidence for the adjectival nature of negative relative verbs comes from the agreement phenomena observed when they are used as modifiers. Negative relative verbs agree with the head noun in case and gender. The morphological means applied to signal agreement are identical to those found on adjectives. Negative relative verbs inflect for three cases and two genders (Table 8). The morpheme -ú found after the negative relative morpheme in Table 7 above is the masculine accusative morpheme; this morpheme is in a paradigmatic relation to other case and gender morphemes, as shown in Table 8 .

Table 8. Case and gender morphology of negative participles

\begin{tabular}{|l|l|l|l|}
\cline { 2 - 4 } \multicolumn{1}{c|}{} & ACC & NOM & OBL \\
\hline M & -umb-ú (see ex. (27)) & -úmb-u (see ex. (24)) & -úmb-o -úmb-ua \\
\hline F & -umb-úta & -úmb-ut (see ex. (26)) & -úmb-o -úmb-uta \\
\hline
\end{tabular}

Table 9 outlines the structure of a negative participle (relative verb).

18 When speaking about Kambaata, the terms "negative relative verb" and "negative participle" are used interchangeably in this paper. 
Table 9. Structure of negative participles

\begin{tabular}{|l|l||l|l|l||l|}
\hline \multicolumn{2}{|l|}{ Stem } & Subject & Negation & Case/gender agreement & (Object suffix) \\
\cline { 1 - 2 } Root & Derivation & agreement & -umb- & with head noun & \\
\hline
\end{tabular}

In spite of gender and case agreement with the head noun, agreement with the subject in person, number, gender and social status of the subject is not lost. The adjectival morphology does not replace the verbal morphology but supplements it (see Table 9). The negative participle qas-úmb-u in ex. (24) above signals that the subject of the relative clause is third person masculine ${ }^{19}$ and that the head is a noun of masculine gender and nominative case. In ex. (26), the noun támit 'benefit' is preceded by a negative participle which agrees with it in feminine gender and nominative case. As támit is not only the subject of the main clause but also of the relative clause, the participle kottúmbut is marked for third person feminine subject agreement.
(26) $\quad[[(\ldots)$ alas-í-na
gardaam-í
daabb-ó
tam-éechch
wheat-M.GEN-CRD2 oat-M.GEN
bread-F.GEN use-F.ABL
kot-túmb-ut]
tám-it] yóo-se
be_not_enough-3F.NREL-3F.NOM benefit-F.NOM COP1.3-3F.OBJ
'(...) it (= enset bread) has a benefit which is not less than the benefit of wheat and oat bread.' (Kambaatissata 5: 28)

As in affirmative relative clauses, the syntactic function or the semantic role of the head noun in the negative relative clause is not indicated; consider ex. (27)-(29), in which the head nouns and the modifying negative participles are all marked for the accusative case. The head noun

\footnotetext{
19 The absence of a subject agreement morpheme before -úmb signals agreement with a 3M or 1SG subject.
} 
is interpreted as the subject of the relative clause in ex. (27), as the object in ex. (28), and as the locative adjunct in ex. (29).

(27) [íi [reh-umb-ú $]$ beet-ú $]$

1SG.GEN die-3M.NREL-M.ACC child-M.ACC

'my living son' / 'my son who has not died'

(28) [[has-eenumb-ú $] \quad$ beenn-á $]$

want-3HON.NREL-M.ACC debt-M.ACC

'unwanted debt' / 'debt which one does not want'

$[[$ wó'-u eel-umb-ú $] \quad$ bucc-á $]$

water-M.NOM stand_of_water-3M.NREL-M.ACC soil-M.ACC

'soil on which there is no standing water'

Negative participles also agree with case- and gender-inflecting enclitics, e.g. the place enclitic $=\mathbf{b a}$; see ex. (30)-(31).

$[[$ reh-eenumb- $\underline{u}]=\mathbf{b b}-\underline{\mathbf{a}}]$

iill-áamm $\quad$-ít

die-3HON.NREL-M.ACC=PLACE-M.ACC reach-1SG.IPV say-3F.PCO

$[[\operatorname{moog}$-eenumb-úu $]=\mathbf{b b - a}] \quad$ iill-itóo’u

bury-3HON.NREL-M.ACC $=$ PLACE- $\underline{\text { M.ACC }}$ reach-3F.PVO

'Expecting that she would reach (a place) where one does not die, she arrived at (a place) where one is not buried.' (Kambaatissata 6: 142)

(31)

$[[$ habár-ch-u iill-úmb- $\underline{\mathbf{u}}]=\mathbf{b b}-\underline{\mathrm{u}}] \quad$ yóo-ba'i-a

enset_leaf-SG-M.NOM reach-3M.NREL-M.NOM=PLACE-M.NOM COP1-NEG.REL-M.COP2

'An enset leaf can be used for anything.' (lit.: “There is no place that an enset leaf does not reach.") 
Negative participles are frequently attested in adverbial clauses, many of which are relative clause-based (Treis 2008b: 190-202); consider the conditional clause in ex. (32). ${ }^{20}$

[[ha'mm-ichch-ú

enset_corms-SG-M.ACC

wees-íta

daqq-íi

enset-F.ACC

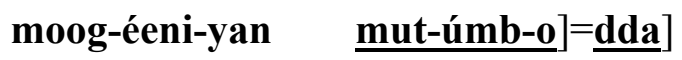

bury-3HON.PCO-DS shoot-3M.NREL-M.OBL=COND

'One cannot gain enset plants if one does not bury an enset corm and it shoots.'

\subsubsection{Pronominal suffixes on negative participles}

Suffixed pronouns occur in the same slot on negative participles and adjectives, namely after the case/gender-morpheme; compare ább-u-nne in ex. (33) and aag-úmb-u-'e in ex. (34). The pronouns on adjectives and negative participles are formally identical. But whereas pronouns on adjectives refer to the possessor of the head noun, ${ }^{21}$ pronouns on negative participles (as on other verbs) encode the direct, indirect or oblique object.

[[ább-u-nne $]$ ánn-u $]$ al-í hangaar-áam-u-a

big-M.NOM-1PL.POSS father-M.NOM body-M.ACC scratch-PROP-M.PRED-M.COP2

(Riddle:) 'Our big father's body is scratchy.' (Kambaatissata 4: 81)

(lit.: "Our big father is scratchy as regards the body.")

$$
\begin{array}{llll}
{[[\text { esáa }} & \text { aag-úmb-u-’e }] & \text { xáw-u }] & \text { yóo'u } \\
\text { 1SG.DAT } & \text { enter-3M.NREL-M.NOM-1SG.OBJ } & \text { issue-M.NOM } & \text { COP1.3 }
\end{array}
$$

'There is something that I did not understand.' (Kambaatissata 4: 78)

(lit.: "There is an issue that did not enter for me / my benefit.")

20 The conditional morpheme $=\mathbf{d a}$ is preceded by a negative participle in the oblique case, which indicates that $=\mathbf{d a}$ could be derived historically from a non-nominative/non-accusative noun.

Dependents pronouns are attached to the end of a noun if the noun is unmodified (ann-á-nne father-M.ACC1PL.POSS 'our father'). However, if the noun is modified, the pronoun moves to the modifier, as in ex. (33). 
It is particularly noteworthy that the object pronouns on negative participles are found outside the adjectival suffixes and are thus not adjacent to other verbal morphology.

\subsubsection{Negative participles as heads of NPs}

It has been shown in section 2 above that adjectives may be used as the heads of NPs without being subjected to nominalisation (Table 3). To a limited extent, this rule also applies to negative participles. Affirmative relative verbs, however, must be nominalised whenever the relative clause is headless and used as an argument. The nominalisation compensates for the absence of the head noun and allows the relative clause to be case-marked. Two nominalising operations have to be distinguished (Table 10). The first operation (NMZ1) is applied when an accusative or nominative head noun is absent. The final vowel of the relative verb is lengthened and a (secondary) case/gender marker is attached, as illustrated in the left columns of the table and in ex. (35).

Table 10. Case and gender endings of nominalised affirmative relative clauses

\begin{tabular}{|c|c|c|c|c|c|c|c|}
\hline & \multicolumn{2}{|l|}{\begin{tabular}{|l|} 
NMZ1 \\
\end{tabular}} & \multicolumn{5}{|l|}{ NMZ2 } \\
\hline & $\mathrm{ACC}$ & NOM & GEN & DAT & $A B L$ & ICP & LOC \\
\hline $\mathrm{M}$ & $\ldots$..v́v(-ha) & ...v́v(-hu) & $=$ hann-í & $=$ hann-íi(-ha) & $=$ hann-íichch & $=$ hann-íin & $=$ hann-éen \\
\hline $\mathrm{F}$ & $\ldots v^{\prime}-\mathrm{ta}$ & ...v́v-t & $=$ tann-é & $=$ tann-ée(-ha) & $=$ tann-éechch & $=$ tann-éen & $=$ tann-éen \\
\hline
\end{tabular}

\section{(a) [[qarabb-ó $]$}

mánch-u]

quarrel-3M.PVO.REL man(.SG)-M.NOM

'the man who quarrelled' 
(b) [harruuchch-íin garabb-óo $(\underline{-h u})] \quad$ gennán-o

donkey(.SG)-M.ICP quarrel-3M.PVO.REL.NMZ1-M.NOM shoulder-M.OBL iyy-áno

carry-3M.IPV

'The one who quarrelled with a donkey carries (the load) on (his own) shoulder.' (Proverb)

If the relative clause has to be encoded in a case form other than nominative or accusative, nominalisation operation 2 (NMZ2) is activated: the head noun is replaced by a gendersensitive enclitic morpheme =hann / =tann; see the right columns of Table 10 and ex. (36). The nominaliser is historically related to the independent proximal demonstrative pronoun ('this') (Treis 2008a: 376ff).

(a) [[xonqa'-anó $] \quad$ manch-íi(ha) $]$

eat_without_milk-3M.IPV.REL $\operatorname{man}(. \mathrm{SG})$-M.DAT

'for the man who eats (bread) without milk'

(b) qaam-anóo(-hu)

eat_with_milk-3M.IPV.REL.NMZ1-M.NOM

$[[\underline{\text { xonqa'-anó }}]=\underline{\text { hann-íi(ha) }})] \quad$ qishixx-áno-ba'a

eat_without_milk-3M.IPV.REL=NMZ2-M.DAT feel_sorry-3M.IPV-NEG

'The one who eats (bread) with milk is not sorry for the one who eats (bread)

without milk.' (Proverb)

Negative participles also undergo NMZ2 when they are marked for a case form other than nominative or accusative and, thus, behave unlike adjectives; see the right half of Table 11. In ex. (37), the headless negative participle is marked for the instrumental-comitative-perlative case. 
type_of_dish-F.ACC new-F.ACC waasa-M.ICP cook-3HON.IPV

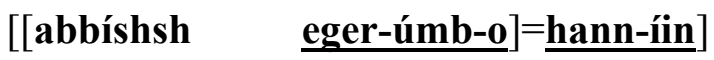

exceed.3M.PCO stay-3M.NREL-M.OBL=NMZ2-M.ICP

'The bilaanbiluta-dish is cooked with new waasa (fermented enset pulp), with one that has not been stored (lit.: "has not stayed") for a long time.'

Table 11. Case and gender paradigm of headless negative participles

\begin{tabular}{|c|c|c|c|c|c|c|c|}
\hline & \multicolumn{2}{|c|}{ NO NMZ NMZ1 } & \multicolumn{5}{|l|}{ NMZ2 } \\
\hline & $\mathrm{ACC}$ & NOM & GEN & DAT & $\mathrm{ABL}$ & ICP & LOC \\
\hline M & $\begin{array}{l}(-\mathbf{u}) \sim \\
\text {-úu(-ha) }\end{array}$ & $\begin{array}{l}\text { '-u } ~ \\
-\mathbf{u} \mathbf{u}(-h \mathbf{u})\end{array}$ & =hann-í & $=$ hann-íi(-ha) & $=$ hann-íichch & $=$ hann-íin & $=$ hann-éen \\
\hline $\mathrm{F}$ & $\begin{array}{l}\text { (-ú-ta) } \\
\text {-úu-ta }\end{array}$ & $\begin{array}{l}2-\mathbf{u}-\mathbf{t} \sim \\
-\mathbf{u} \mathbf{u}-\mathbf{t}\end{array}$ & $=$ tann-é & $=$ tann-ée(-ha) & $=$ tann-éechch & $=$ tann-éen & $=$ tann-éen \\
\hline
\end{tabular}

NMZ1 is reflected in vowel lengthening and stress shift: either the vowel of the first case/gender morpheme ( $\mathbf{u} \rightarrow \mathbf{u u}$ ) or of a suffixed pronoun following this morpheme is lengthened and stressed. Although negative participles are often nominalised when they are marked for accusative or nominative case (see the forms with long vowels in the accusative/nominative columns of Table 11), there are contexts in which nominalisation is suspended and in which negative participles, like adjectives, are used as the head of an NP without further measures being taken (see the forms with short vowels in the accusative/nominative columns of Table 11). ${ }^{22}$ The conditioning factors for the suspension of the nominalisation operation are difficult to pin down; they are describable but not explicable

22 In Treis (2008b) it is erroneously assumed that the nominalisation of the accusative and nominative negative participles is not common. However, a larger data corpus revealed that nominalisation is rather the rule and the absence of nominalisation the exception. 
at the present state of knowledge. In the nominative case, the nominalisation of masculine forms is generally not necessary (38), unless a suffixal pronoun is added (39).

$\begin{array}{llll}\text { [Giib-íta } & \underline{\text { xuud-úmb-u }}] & \text { Gamun-án }^{23} & \text { saad-áno } \\ \text { Omo-F.ACC } & \text { see-3M.NREL-M.NOM } & \text { Gamuna-M.ACC } & \text { admire-3M.IPV }\end{array}$

'The one who has not seen the Omo (river) admires the Gamuna (creek).' (Proverb) (Berhanu Mathewos 1986: 68) $)^{24}$

\section{[hujat-umb-u-síi-hu]}

work-3M.NREL-M.NOM-3M.POSS/OBJ.NMZ1-M.NOM

\section{sharr-ámm-ee’u}

chase-PASS-3M.PVE

1. 'The one who did / does not work for him was chased away.'

2. 'One (from the aforementioned group) who did / does not work was chased away.'

The nominalisation of feminine nominative forms is not required if no pronoun occurs on the negative participle and if the implicit head noun functions both as the subject of the main and the relative clause. Elsewhere, nominalisation is indispensable; see ex. (40) in which the "missing" head noun is the subject of the main clause but the object of the relative clause.

[gíir-at qok-kumb-úu-t]

fire-F.NOM affect-3F.NREL-F.NOM.NMZ1-F.NOM

\section{danáam-o=gg-a}

good-M.OBL=SIM-M.OBL

\section{laashsh-itáa'u}

grow.CAUS-3F.IPV

'The one (= land) which fire did / does not affect produces well.'

Cleft sentences are prevalent in Kambaata texts. Headless relative clauses marked for nominative case and masculine gender are used in cleft sentences to encode the non-focused background information (see the clause headed by dandinumbúu(-hu) in ex. (41)), while the

\footnotetext{
23 The correct transcription of the second river name is not known.

24 I have segmented and glossed the data from Berhanu Mathewos (1986) and converted them to the official orthography.
} 
focused constituent occurs as the complement of a copula (see míihaat in ex. (41)). Negative relative clauses in cleft sentences are always nominalised (NMZ1).

[mexx-é ronsoomm

roshsh-áta da'll-ín

hab-íi

one-TIMES learn.1PL.PVO.REL habit-F.ACC do_quickly-1PL.PCO-N forget-M.DAT dand-inumb-úu(-hu)] m-íihaa-t?

can-1PL.NREL-M.NOM.NMZ1-M.NOM what-M.DAT.VV-COP3

'Why can't we quickly abandon habits that we have learned once?' (lit.: "Why is it that we can't quickly forget habits which we have learned once?")

In the accusative case (see the first column in Table 11), nominalisation is only exceptionally absent; the three attested non-nominalised examples ${ }^{25}$ are called into question by the much larger number of utterances both from texts and elicitation in which nominalisation is compulsory. In ex. (42) a nominalised negative participle is used in apposition to an accusative object (note that the secondary case/gender-marker -ha is realised -ka after a nasal).

\section{ii beet-ú, [reh-umb-úu-n-ka],}

1SG.GEN child-M.ACC die-3M.NREL-M.ACC.NMZ1-N-M.ACC

$$
\begin{array}{ll}
\text { reh-ee'íi(-ha) } & \text { ass-itóo'u } \\
\text { die-3M.PVE.REL.NMZ1-M.ACC } & \text { do-3F.PVO }
\end{array}
$$

'She declared (lit.: "made") my son, the one who had not died, to be the dead one.'

The accusative case is poly-functional in Kambaata; it encodes the citation form of nouns and it is the case form of direct objects, goals, and adverbial phrases (Treis 2008a: 117f).

Consequently, headless relative clauses in the accusative form are not only used as masculine direct objects of a verb (as in ex. (42)) but they may also have adverbial function. As accusative-marked concomitance clauses they encode accompanying circumstances. The

\footnotetext{
25 It remains to be checked whether these counter-examples can be attributed to transcription errors.
} 
semantic relation between the concomitance clause and the superordinate clause is not overtly specified and has to be inferred from the context; see the two coordinate negative clauses in ex. (43). Concomitance clauses are invariantly marked for masculine gender and they are always nominalised.

\section{[maxín-it bata'-umb-uu-háa]}

salt-F.NOM be too_much-3F.NREL-M.ACC.NMZ1-M.ACC.CRD1

[kot-tumb-uu-háa]

be_not_enough-3F.NREL-M.ACC.NMZ1-M.ACC.CRD1 nice-M.ACC coffee-M.ACC gáff éeb!

boil.2SG.PCO bring.2SG.IMP

'Boil and bring good coffee with the proper amount of salt!' (lit.: "Salt being not too much and not being insufficient, boil and bring good coffee!’)

\subsubsection{Neutralisation of aspectual distinctions}

Negative participles share another important semantic similarity with adjectives. While affirmative relative verbs are marked for imperfective, perfective (e-perfective and $\mathbf{0}$ perfective) or progressive aspect, these aspectual distinctions are completely neutralised in the negative participle paradigm, a fact which has been noted as early as in Leslau (1952): "If my records are exact the forms of the relative with the [negative] present are the same as those of the relative with the negative perfect" (p. 356). Negative participles express an unbounded state of 'not V-ing' or 'not having V-ed' and thus they exhibit a temporal structure which is similarly unbounded to the qualities that are conveyed by adjectives; see, e.g., ex. (44), in which the negative participle occurs in a chain between two adjectives. 


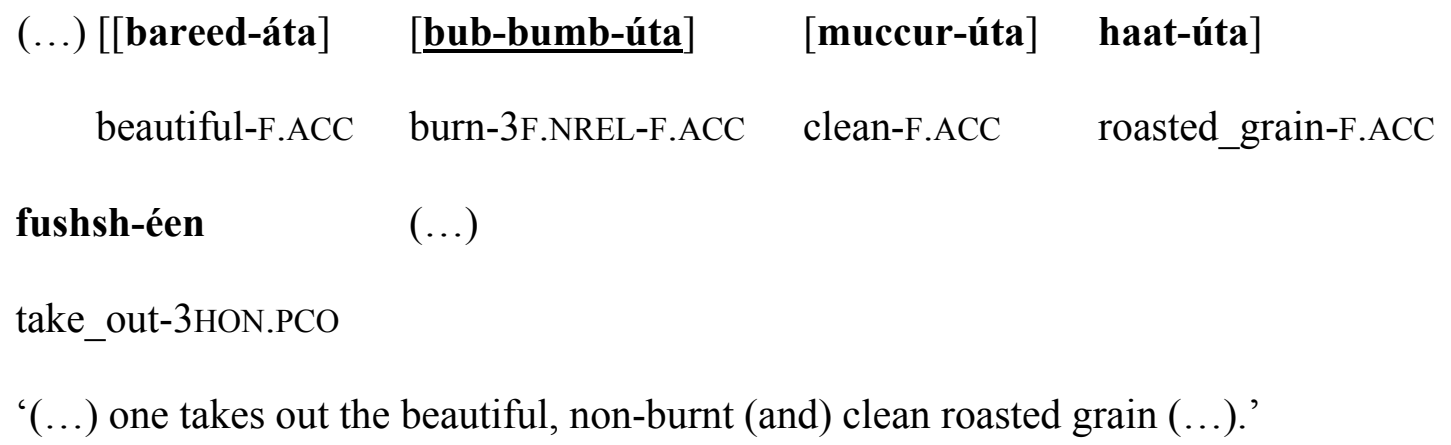

The interpretation of negative participles as expressing a constant, habitual, repeated or incomplete (i.e. imperfective) 'not V-ing' versus a single instance of a completed (i.e. perfective) 'not V-ing' is only provided by the context. If we look back at ex. (27) and (30), (excerpts of) which are repeated below, one can see that the negative participle form of reh'die' has an imperfective interpretation in ex. (30)' and a perfective interpretation in ex. (27)'. (30)' $[[\underline{\text { reh-eenumb-ú }]}=\underline{b b-a}] \quad$ iill-áamm $\quad$ y-ít $(\ldots)$ die-3HON.NREL-M.ACC=PLACE-M.ACC reach-1SG.IPV say-3F.PCO 'Assuming that she would reach (a place) where one does not die, (...).' (Kambaatissata 6: 142)

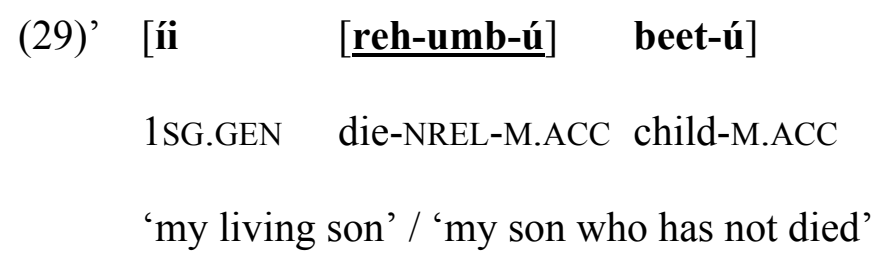

Although there is a conspicuous phonological similarity between the marker of negative participles, -um-b-, and the marker of perfective or, more precisely, non-imperfective negative main verbs, -im-bá('a), there is no evidence that a perfective reading of a negative participle is generally preferred to an imperfective reading. Quite the contrary, negative participles are sometimes negated periphrastically in order to signal 'not having V-ed' / 'not yet having V-ed' explicitly. For this purpose, a negative converb is made dependent on a relative form of the verb fa'- 'remain'; consider ex. (45). Such periphrases, however, are less 
common in my corpus than the use of the potentially ambiguous negative participles in the context of a single instance of 'not V-ing'.

[[qalam-á buur-an-tu'nnáan fá'-ee

ma'nn-íta] dágg-o

paint-M.ACC smear-PASS-3F.NCO remain-3F.PVE.REL place-F.ACC find-3M.PVO 'He found a spot which had not (yet) been painted (lit.: "which had remained nonpainted").'

\subsection{Summary of the properties of negative participles}

Negative relative verbs (participles) in Kambaata are almost perfect verb-adjective hybrids (Table 12). As modifiers of nouns they share the case and gender morphology and the stress pattern with adjectives and they have thus the same means to display case and gender agreement with the head noun. Affirmative relative verbs are no categorial hybrids and unable to agree with their head noun. Like adjectives, negative participles are unmarked for aspect; the aspectual paradigms of the affirmative relative verbs are conflated in one single aspectneutral negative paradigm.

Table 12. Verbal and adjectival properties of negative participles

$+\mathrm{V}: \quad \quad \quad \quad$ Negative participles have an entirely verbal argument structure.

$+\mathrm{V}: \quad$ Negative participles agree with their subjects; the subject agreement morphemes are identical to those found on verb forms of other paradigms.

$+\mathrm{V} \quad$ Pronominal suffixes on negative participles refer to objects.

$+\mathrm{V}$ Negative participles are usually nominalised when used as NP-heads.

+ A: $\quad$ Negative participles inflect like adjectives of declension A2 in -ú(-ta) and agree with their nominal heads in case and gender.

+ A: $\quad$ Aspectual distinctions are completely neutralised and negative participles express an unbounded state of 'not V-ing'. 
$+\mathrm{A} /+\mathrm{N}$ : $\quad$ In a few contexts, negative participles can be used as NP-heads without being nominalised.

Although the external (morpho-)syntax is much like that of adjectives, the internal (morpho-)syntax of negative participles is clearly that of verbs. They govern subjects and objects as well as adverbial constituents, e.g. subordinate and co-subordinate adverbial clauses; see the converb clause headed by xúudd which is dependent on the negative participle in ex. (46). In contrast to this, adjectives are incapable of governing adverbial constituents apart from degree adverbials. As heads of relative clauses, negative participles have the same syntactic potential as verbs that are used as heads of main clauses.

\begin{tabular}{|c|c|c|c|}
\hline [[[káan & xúud-d] & ill-í-ssa & amma'nn-itúmb-u] \\
\hline IDEM.M.ACC & see-3F.PCO & eye-F.ACC-3PL.POSS & believe-3F.NREL-M.NOM \\
\hline ciil-uhúu & \multicolumn{2}{|c|}{ wosh-ichch-uhúu] (...) } & \\
\hline boy-M.NOM. & 2D1 dogs- & -M.NOM.CRD1 & \\
\hline
\end{tabular}

The morphological potential of negative participles is less elaborate than that of main verbs, because negative participles are unmarked for aspect and, like other (co-)subordinate verbs (e.g. affirmative relative verbs, converbs), they cannot be marked for mood. However, negative participles show agreement with their subjects. For this purpose, they have five different agreement morphemes depending on the person, gender, number and social status of the subject. Negative participles thus distinguish as many subject agreement morphemes as, for instance, negative non-imperfective main verbs. Pronominal suffixes on negative participles refer to the direct, indirect or oblique object (but not to the subject). When used as heads of an NP, the behaviour of negative participles is not unequivocally adjective-like or verb-like. There are a small number of contexts in which negative participles, 
like adjectives, can be used as NP-heads without further measures being taken but mostly they have to undergo the same nominalisation procedures as affirmative relative verbs.

\section{Agent Adjectives}

Apart from the negative participles discussed in the previous section, Kambaata has a second type of verbal adjectives, so-called "agent adjectives" (AAs), ${ }^{26}$ which combine verbal and adjectival features in a conspicuous way. The agentive morpheme -aan (Treis forthcoming a) generates adjectives on the basis of verbs, e.g. ros- 'learn' $\rightarrow$ ros-aan-ch-ú(-ta) (M/F) 'learner, student'. The input of the formation may be bare or extended verb stems, e.g. il'give birth', il-siis- 'assist / cause to give birth' $\rightarrow$ il-siis-aan-ch-ú-ta (F) 'midwife', xa'mm'ask', xa'mm-am- 'be asked' $\rightarrow$ xa'mm-am-aan-ch-ú (M) 'person asked, interviewee'. The agentive morpheme is obligatorily followed by at least two morphemes, a number morpheme (-ch singulative or -n plurative) and a case suffix (-ú in the citation form). Feminine AAs receive an additional gender morpheme in certain case forms (-ta in the citation form). Derived forms such as ros-aan-ch-ú 'learner, student' are verb-adjective hybrids. They are considered to be partially adjectival in nature, because they agree in case and gender with their head noun when they are used as modifiers; see ex. (47)-(49). Like other Kambaata adjectives (recall Table 2 above), AAs differentiate three cases (accusative, nominative, oblique) and two genders (masculine and feminine) when used attributively.

26 Admittedly, the term "agent adjective" is problematic, because the adjective does not always characterise or refer to the agent of an action. It has been suggested to use the term "subject adjective" instead, in order to account for the fact that adjectives can also be derived from verbs (e.g. passive verbs, verbs of experience) that take non-agentive subjects. However, the term "subject adjective" is equally problematic in reference to the small group of adjectives that characterise or refer to non-subject arguments of the base verb and in reference to adjectives that are derived from nouns (see examples below). 
(Kambaatissata 8: 21)

qaaxx-áan-ch-o (M.OBL) sa'-íi (M.DAT) 'for the insatiable cow'

$(<$ qaaxx- 'be(come) insatiable')

AAs display another syntactic peculiarity which is characteristic of adjectives in Kambaata. The head noun of an adjective (mann-á in ex. (50)-(a)) may be absent in its usual position and instead be added as a genitive modifier to the adjective (see ex. (50)-(b)). Thus, the dependency relation is reversed and the adjective is foregrounded. The comparison of the proverbs given in ex. (51)-(52) illustrates that the use of AAs in such constructions is as appropriate as the use of primitive adjectives.
(a) hoolam-á mann-á $\rightarrow$
(b) mann-í
hoolam-á
many-M.ACC people-M.ACC
people-M.GEN many-M.ACC
'many people' 'many people' (lit.: “many of people”)

ga"'í bareed-á yeenn-í híil-u ba'-íshsh-o.

call-M.GEN nice-M.ACC yes-M.GEN bad-M.NOM spoil-CAUS-3M.PVO

'An impolite yes destroys a polite call.' (lit.: “A bad of a yes destroys a nice of a call.”) (Proverb)

\section{iz-eechch-ó}

\section{$\underline{\text { mogga'-aan-ch-úta }}$}

nubaachch-í

qophphan-aan-ch-ú

bride-SG-F.GEN steal-AA-SG-F.ACC old_person.SG-M.GEN lie-AA-SG-M.ACC '(Beware of) a bride who steals and an old man who lies.' (lit.: “(Beware of) a thief of a bride and a liar of an old man.") (Proverb) (Berhanu Mathewos 1986: 14)

All Kambaata adjectives, including AAs, can be used as heads of noun phrases without further measures being taken. In this syntactic function, they inflect exactly like nouns and distinguish as many case forms as nouns: accusative, nominative, genitive, dative, ablative, 
instrumental-comitative-perlative, locative and oblique. AAs are in fact used as heads of NPs much more often than as modifiers and they could easily be mistaken for nouns if their agreement potential was not considered. In ex. (53), two AAs are used as heads of an ablative NP and of a nominative subject NP, respectively.

$\begin{array}{llll}\text { xah-í } & \underline{\text { dimb-aan-n-íichch }} & \text { seel-í } & \underline{\text { dimb-áan-ch-u }} \\ \text { word-M.GEN } & \text { be_drunk-AA-PL-M.ABL } & \text { beer-M.GEN } & \text { be_drunk-AA-SG-M.NOM } \\ \text { woyy-áno } & & & \end{array}$

be_better-3M.IPV

'A beer drunkard is better than word drunkards.'

Like nouns (and adjectives), AAs can be modified by genitive nouns (54) and adjectives (55) when they are used as the head of an NP.

mixaad-í shiinsh-aan-ch-ú

griddle-M.GEN wipe-AA-SG-M.ACC

'griddle wiper' (lit.: “wiper of griddle”)

\section{woyy-á lallab-aan-ch-ú}

better-M.ACC speak_in_public-AA-SG-M.ACC

'better orator'

In spite of their adjectival and nominal properties, AAs also reflect the argument structure of their verbal bases. ${ }^{27}$ They are able to govern objects; see ex. (56)-(57). AAs cannot govern subjects, which is intuitively plausible because the very function of the agentive formation is to generate word forms that refer to the agent (syntactic subject) of the base verb.

\footnotetext{
27 The verbal features are definitely "inherited" from the verbal base, because the small group of -aan-derivates that are derived from nouns (Treis forthcoming a) are devoid of verbal properties.
} 
(56)

gayy-áta qadiid-aan-ch-ú

pipe-F.ACC be_addicted-AA-SG-M.ACC

'pipe addict'

ga'mm-eennó $=\mathbf{r}-\mathbf{a}$

bite-3HON.IPV=NMZPL-M.ACC gaaz-áan-ch-o

persecute-AA-M.VOC

'(you) persecutor (of) the ones who are bitten' (Kambaatissata 4: 33)

Although AAs are commonly modified by adjectives (see ex. (55)), they may also be modified by adverbs; see danáamoga in ex. (58).

$$
\begin{aligned}
& \text { (...) danáam-o=g-a xawaaqq-aan-ch-ú ass-íi dand-áno } \\
& \text { good-M.OBL=SIM-M.OBL speak-AA-SG-M.ACC do-M.DAT be_able-3M.IPV }
\end{aligned}
$$

'(A sound rhetorical education) can produce a good (lit.: “well”) speaker.'

Furthermore, AAs are capable of governing more or less elaborate co-subordinate clauses; see the converb clauses preceding the AAs in ex. (59)-(61).

$$
\text { maqées-s it-áan-ch-o }
$$

do_with_force-2SG.PCO eat-AA-SG-M.OBL

'(you) forceful eater' (lit.: “forcefully eater”) (Kambaatissata 4: 33)

(60) gamball-á ít-t wojj-ú cin-áan-ch-o

black-M.ACC eat-2SG.PCO white-M.ACC shit-AA-SG-M.OBL

'(you) black eat(er) (and) white shitter' (Kambaatissata 4: 33)

(61) ga"-aqq-án-t beeqq-án-t it-áan-ch-o

call-MID-PASS-2SG.PCO share.MID-PASS-2SG.PCO eat-AA-SG-M.OBL

'(you) assemble(r), share(r) (and) eater' / 'you who eats having assembled (others) and shared (with them)' (Kambaatissata 4: 33)

It is not yet clear what makes speakers prefer an [Object V-]aan-ch-ú to a [Genitive] [V-

]aan-ch-ú construction. Whereas in certain cases, all speakers interviewed voted unanimously 
for a genitive modifier (e.g. in the case of qabal-é (F.GEN) gashsh-aan-ch-ú 'qäbäle ruler', lit.: "ruler of a qäbäle (smallest administrative unit in Ethiopia)") or an accusative complement (e.g. in the case of heess-á (M.ACC) kul-aan-ch-ú 'story teller'), in many other cases some informants preferred the complement construction, some the genitive construction, and others even considered both as equally possible (e.g. in the case of oddishsh-á-ta (F.ACC) / oddishsh-á (F.GEN) gob-aan-ch-ú 'tailor', lit.: “clothes sewer / sewer of clothes").

In Table 13 the verbal $(+\mathrm{V})$, adjectival $(+\mathrm{A})$ and nominal $(+\mathrm{N})$ properties of AAs are summarised. ${ }^{28}$ Note that some properties can signal membership in both the word classes Adjective and Noun.

Table 13. Verbal and adjectival properties of agent adjectives

$+\mathrm{V}$ : AAs have a (partly) verbal argument structure: they can govern objects, dependent clauses, and (rarely) adverbs.

$+\mathrm{V}$ : $\quad$ AAs can contain verbal derivational morphology (e.g. passive, middle).

+ A: $\quad$ AAs inflect like adjectives of declension A2 in -ú(-ta) and agree with their head nouns in case and gender.

+ A: $\quad$ AAs can occur in modifier-foregrounding constructions.

$+\mathrm{A} /+\mathrm{N}$ : The object of the base verb can occur as a genitive modifier on the AA.

$+\mathrm{A} /+\mathrm{N}: \quad$ AAs are usually modified by adjectives rather than adverbs.

$+\mathrm{A} /+\mathrm{N}$ : $\quad$ AAs are devoid of verbal inflectional morphology (subject agreement, aspect, polarity, mood).

$+\mathrm{A} /+\mathrm{N}$ : $\quad$ AAs are used as heads of an NP without further measures being taken.

28 No data are available on the interpretation of pronominal suffixes, though I would expect them to express the possessor of the referent encoded by the AA. 
AAs are definitely less verbal than negative participles. The most important difference between these categorial hybrids is the complete lack of verbal inflectional morphology on AAs. Furthermore, AAs are often modified by genitive nouns, but this is never attested for negative participles. Although AAs seem to be the affirmative counterparts of negative participles in contexts such as ex. (62) - in which an AA and a negative participle are coordinated and in which both the AA and the participle refer to the agent/subject of the verb they are based on - it would not be correct to consider negative participles to be negative AAs. The actual or implicit head noun of a negative participle does not have to be interpreted as the subject of the negative participle/relative clause but, as for affirmative relative verbs, it may assume any syntactic function in this clause. Negative participles are first and foremost the negative counterpart of affirmative relative verbs, but given the lack of negative AAs they also adopt this function, as in ex. (63).
(...) hór-unku
mánn-u,
ag-aan-ch-uhúu

all-M.NOM $<\mathrm{N}>$ people-M.NOM drink-AA-SG-M.NOM.CRD1

ag-umb-uhúu

y-únku,

(...)

drink-3M.NREL-M.NOM.CRD say-M.NOM $<\mathrm{N}>$

iitt-anó-si-a

ágg-a

y-ú-a

like-3M.IPV-3M.OBJ.REL-M.COP2 drink-M.PRED say-M.PRED-M.COP2

'(...) this is to say that (the qaaribo-drink) is a drink which everybody, i.e. (alcohol)

drinkers and non-drinkers, (...) like.'

(63)

ag-aan-ch-ú

ag-anóo(-ha)

ag-umb-ú 'drinker' (AA)

'the one / someone who drinks' (REL)

'non-drinker', 'the one / someone who does not drink'

The -aan-formation is, to a certain extent, semantically irregular, because not all -aanderivatives have an agentive interpretation. As demonstrated in Treis (forthcoming a), -aan- 
derivatives may sometimes, unpredictably, refer to instruments, containers or patients other than the agent of the action expressed in the base verb; see, e.g., qeessis- 'produce cheese' $\rightarrow$ qeessis-aan-ch-úta '(dish) with / in which cheese is produced' and maxxag- 'lead on the rein, carry on the handle' $\rightarrow$ maxxag-aan-ch-ú '(pot) which is carried on the handle'. Apart from this, there are a few instances in which -aan is attached to nominal bases, e.g. zeem-áta 'herding' $\rightarrow$ zeem-aan-ch-ú 'shepherd', maz-áta 'wound' $\rightarrow$ maz-aanch-ú 'wounded (person)', qomaax-á 'leprosy' $\rightarrow$ qomaax-aan-ch-ú 'leprous, leper'.

\section{Masdars}

Kambaata masdars (verbal nouns) are categorial hybrids that combine verbal and nominal properties. Masdars can be segmented into a verbal stem and a case-morpheme of the masculine -ú-declension (declension M3). The stem may be a bare root or a root plus one or several derivational morphemes (passive, causative, middle): xuud- 'see' $\rightarrow$ xuud-ú 'seeing', xuud-am-ú 'being seen', xuud-is-ú 'showing' (lit.: “causing to see”), xuud-aqq-ú 'seeing oneself', xuud-aqq-am-ú 'seeing each other', etc. As members of declension M3, masdars distinguish as many case forms as primitive nouns: xuud-ú accusative, xúud-u nominative, xuud-í genitive, xuud-íi dative, xuud-íichch ablative, xuud-íin instrumental-comitativeperlative, xuud-óon locative and xúud-o oblique. Masdars are used as heads of noun phrases and they are case-marked according to the syntactic function they have in a clause, e.g., as a nominative-marked subject (64), an ablative-marked adjunct (65), an accusative-marked direct object (66) or a genitive-marked modifier (67).

$$
\begin{aligned}
& \text { (...) ang-áta saamun-iiníi wo'-iiníi } \\
& \text { áa'll-u } \\
& \text { hand-F.ACC } \\
& \text { soap-M.ICP.CRD1 water-M.ICP.CRD1 }
\end{aligned}
$$

has-is-áno

want-CAUS-3M.IPV

'(...) washing (one's) hands with soap and water is necessary.' (Kambaatissata 4: 117) 
eat-3HON.IPV.REL=NMZPL-M.ACC buy-M.ABL money-M.ACC-3M.POSS

haraq-éen xoof-áyyoo'u

local_brandy-F.LOC finish-3M.PROG

'Instead of (lit.: “from”) buying food, he is spending his money on local brandy.'

(66)

(...) i-hé ta'mm-í-na ta'mm-ú

i-M.ACC use.MID-M.GEN-CRD2 use.MID-M.ACC not_do-M.GEN-M.COP2

séer-a

rule-M.OBL

'(...) is a rule about (lit.: “of”) using and not using an i-(vowel).' (Maatewoos Shagana 1992: 14)

In spite of these nominal properties, masdars retain their verbal argument structure almost completely. Masdars can govern objects of all kinds; see, for instance, the accusative object má 'what?' in ex. (67).

"hór-unku=rr-u

ros-am-anóo

all-M.NOM $<\mathrm{N}>=$ NMZPL-M.NOM learn-PASS-3M.IPV.REL.NMZ1.M.NOM

kánni-a=gg-a" y-ú-kki’nne

IDEM.M.GEN-M.COP2=SIM-M.PRED say-M.NOM-2HON.POSS

m-á $\quad$ y-ú-a-n?

what-M.ACC say-M.ACC-M.COP2-Q

'What do you mean by saying that everything can become a habit like this?' (lit.:

"Your saying 'Everything becomes a habit like this!' is saying what?”) (Kambaatissata 4: 17)

Like fully or partially finite verbs, they can govern (co-)subordinate clauses. In ex. (68), the masdar ítu 'eating' governs the two preceding converb clauses headed by ful-án 'climb and 
...' and dirriisán 'take down and ...,' respectively. In ex. (67) above, a sentence in direct speech is dependent on the masdar yúkki'nne.

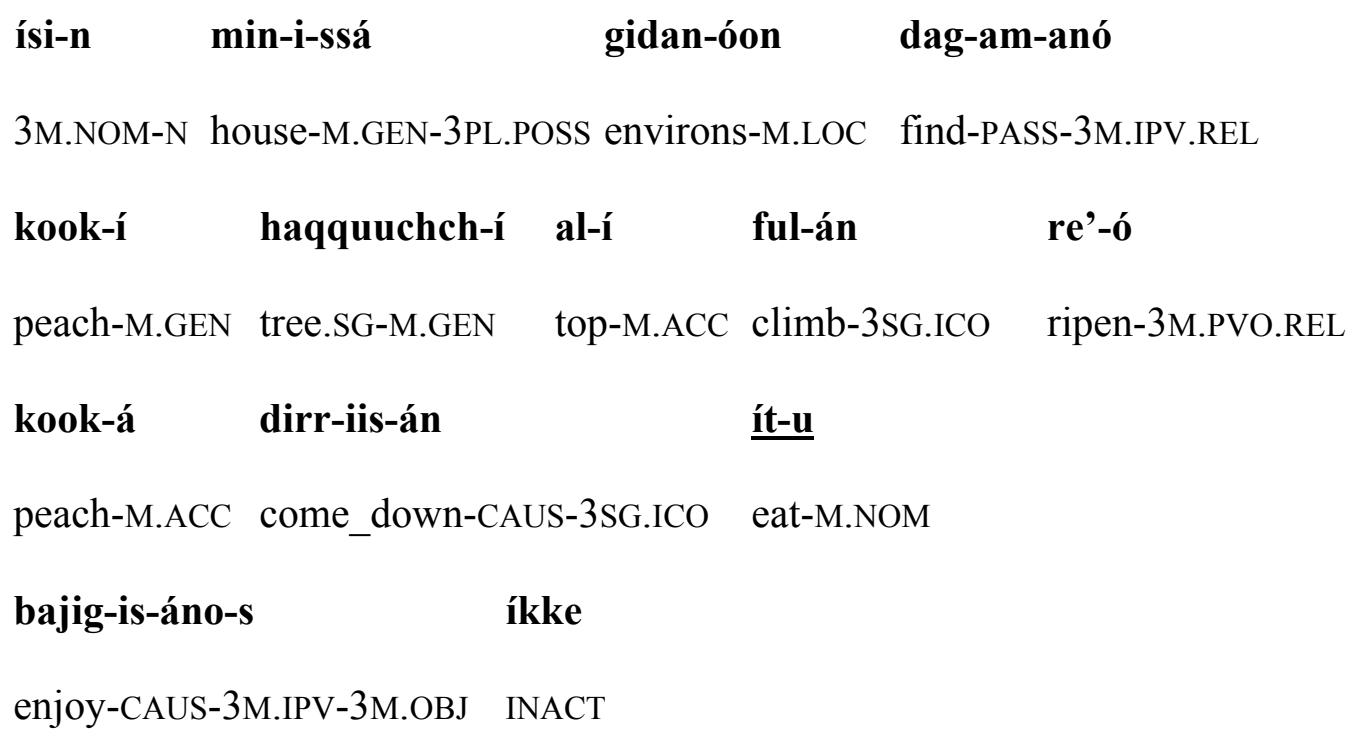

'He enjoyed climbing onto a peach tree close to their house, picking and eating ripe peaches.' (lit.: “... eating ripe peaches pleased him.”) (Kambaatissata 4: 45)

Masdars control nominative subjects, which is another important indicator of the retained verbal argument structure. In ex. (69), Sabíru is the subject of the headless relative verb daggóohu 'that he knew', whereas ámas 'his mother' is the subject of the masdar xidamú 'being ill', which constitutes the head of a complement clause. Hardly ever is the subject demoted to a genitive modifier, as in ex. (70), where Maatabó 'of Matabo' states the agent of the event expressed by the masdar yaaróon 'upon shouting'.
Sabír-u ám-a-s
$\underline{\text { xid-am-ú }}$
dagg-óo-hu

S.-M.NOM mother-F.NOM-3M.POSS make_ill-PASS-M.ACC know-3M.PVO.REL-M.NOM

$$
\text { am-a-sí béet-u xaaff-ó daddaabb-éechchee-t }
$$

mother-F.GEN-3M.POSS child-M.NOM write-3M.PVO.REL letter-F.ABL.VV-COP3

'It was from the letter written by the son of his mother that Sabiro learned that his mother was sick.' (lit.: “... that Sabiro knew his mother being ill.”) (Kambaatissata 8: 


Maatab-ó sakki-sí $\quad$ yaar-óon
M.-F.GEN third-3M.POSS shout-M.LOC crowd-F.NOM go_out-3F.NCO
fa'-oo'íi
m-íihaa-t?
remain-3M.PVO.REL.M.ACC what-M.DAT.VV-COP1
'Why did the people not rush out again when Maatabo shouted a third time (lit.: “...
upon Maatabo's third shouting”)?' (Kambaatissata 4: 136)

As a third possibility, the agent of the event expressed by the masdar can be encoded by a pronominal suffix. Kambaata has two, formally almost indistinguishable, paradigms of pronominal suffixes, one of which is used to encode objects on verbs (e.g. xuudáan-ssa 'I see them'), the other one employed to encode possessors on nouns (e.g. miní-ssa 'their house'). Possessive and object pronouns are only slightly different in the first and second person singular (Treis 2008a: 338-352). The pronominal suffixes occurring on masdars can be shown to be identical to those found on primitive nouns; compare ex. (71) and (72).

$$
\text { gizz-á isíi aass-ú-ḱk }
$$

(*aass-ú-kke)

dag-áamm money-M.ACC 3M.DAT give-M.ACC-2SG.POSS give-M.ACC-2SG.OBJ know-1SG.IPV 'I know that you gave the money to him.'
(72) gujjj-ú- $\underline{\mathbf{k k}}$
(*gujj-ú- $\underline{\text { kke })}$
back-M.ACC-2SG.POSS back-M.ACC-2SG.OBJ
'your back'

Unlike pronominal suffixes on (partially) finite verb forms, pronominal suffixes on masdars cannot be interpreted as referring to the object but only to the subject; see the suffix -ssa 3PL 'their' (but: *'for them') on the ablative masdar in ex. (73) or the suffix -kki'nne 2HON 'your' (but: *'you', *'for you') on the nominative masdar yú 'saying' in ex. (67) above. ${ }^{29}$ It is often

\footnotetext{
29 Depending on the argument structure of the verb they are attached to, pronominal suffixes can refer to a direct (accusative) object, an indirect (dative) object or an oblique object. All these interpretations are ruled
} 
the case that the subject of a masdar is expressed twice, by a full nominative NP as well as by a pronominal suffix; see ex. (74). ${ }^{30}$

$\begin{array}{lll}\text { wol-ú=bb-a } & \underline{\text { orooqq-íichchi-ssa }} & \text { bír-e (...) } \\ \text { other-M.ACC=PLACE-M.ACC } & \text { go_out-M.ABL-3PL.POSS } & \text { front-F.OBL }\end{array}$

(In a horticultural text:) 'Before they are transplanted (...).' (lit.: 'Before their going out to another place (...).”) (Kambaatissata 8: 9)

\section{hugaaxáann-u-s qee'rr-ú-ssa}

hunters-M.NOM-3M.DEF be far-M.ACC-3PL.POSS

mooshsh-eemmá=hann-íichch

zakk-íin (...)

make_sure-3HON.PVO.REL=NMZ2-M.ABL after-M.ICP

'After he had made sure that the hunters were far, (...).' (lit.: “After he had made sure the hunters their being far ...") (Kambaatissata 4: 76)

The interpretation of a pronominal suffix on a masdar as the possessor of the event is a nominal feature which sets masdars apart from all other verb forms in the language. The encoding of arguments of masdars in Kambaata follows the general pattern observed in cross-linguistic studies on the syntax of verbal nouns: If a language allows only one argument of a verbal noun to be marked by a genitive/possessive morpheme, it is the subject while the object retains the clausal object marking (Comrie 1976; Malchukov 2006: 976). The properties of masdars are summarised in Table $14 .^{31}$

out for pronominal suffixes on masdars.

30 According to Baye Yimam (1988), a nominative subject must co-occur with a possessive suffix on the verbal noun in Oromo (East Cushitic).

31 Note that many of the features given here are also shared by verbal nouns ("infinitives") in the East Cushitic language Oromo as described in Baye Yimam (1988). 
Table 14. Verbal $(+\mathrm{V})$ and nominal $(+\mathrm{N})$ properties of masdars ${ }^{32}$

$+\mathrm{V}$ : Masdars have a verbal argument structure: they can govern objects of all kinds, nominative subjects and dependent clauses.

+V: Masdars can contain verbal derivational morphology (e.g. passive, middle).

$+\mathrm{N}$ : Masdars are devoid of verbal inflectional morphology (subject agreement, aspect, polarity, mood)

$+\mathrm{N}$ : Masdars inflect like masculine nouns of the M3-declension in -ú.

$+\mathrm{N}$ : Pronominal suffixes on masdars encode the agent of the event.

Masdars and other derived action nouns should not be confused with one another. Masdars are generated regularly from all verbs through the additional case/gender-morpheme -ú and they are best characterised as verb-noun hybrids. Action nouns, such as those given in the left column of ex. (75), are derived from verbs through various, lexically determined mechanisms (Treis 2008a: 157-171); they are entirely nominal in nature.

$$
\begin{array}{ll}
\text { yaar-an-áta 'cry, shout' } & <\text { yaar- 'cry' } \\
\text { chir-itt-á 'walk' } & <\text { chír y- 'take a walk' } \\
\text { mar-anch-áta 'walk, journey' } & <\text { mar-am- (PASS) 'walk' } \\
\text { dikk-ishsh-áta 'support' } & <\text { dikk-is- (CAUS) 'support' } \\
\text { aag-g-á 'entering' } & <\text { aag- 'enter' } \\
\text { gob-b-á 'weaving, sewing' } & <\text { gob- 'weave, sew' } \\
\text { hooq-áta 'reconciliation, mediation' } & <\text { hooq- 'reconcile, mediate' } \\
\text { jabaat-í' 'serious diarrhoea' } & <\text { jabaat- 'have serious diarrhoea' } \\
\text { hugaax-úta 'hunt' } & <\text { hugaax- 'hunt' }
\end{array}
$$

32 In Malchukov's typology of nominalisation, Kambaata joins the languages on stage 6 of the deverbialisation cline (e.g. Abkhaz) where verbal nouns have lost the categories of illocutionary force, mood, tense and aspect but where voice and valency-changing morphology have been retained (Malchukov 2006: 988). 


$$
\text { gaaz-ú 'war, campaign' gaaz- 'wage war' }
$$

Some action nouns contain verbal derivational morphology, e.g. a passive or a causative morpheme, and thus they fulfil the second criterion from the list of verbal and nominal properties (Table 14). However, there is no indication whatsoever that these action nouns retain the argument structure of their base verbs.

\section{Conclusion}

Kambaata negative participles (negative relative verbs), masdars (verbal nouns) and agent adjectives have been shown to combine properties of two different word classes each. They can neither be said to be only verbs nor only adjectives or nouns. However, the properties of the two word classes are not mixed in an arbitrary way. In accordance with Haspelmath (1996), two word class types are distinguished for the analysis of hybrid categories in Kambaata: (i) the base word class / lexeme word class and (ii) the acquired word class / word form word class. ${ }^{33}$

Table 15. Lexeme and word form word classes

\begin{tabular}{|l|c|c|}
\cline { 2 - 3 } \multicolumn{1}{c|}{} & Lexeme word class & Word form word class \\
\hline Negative participles & Verb & Adjective \\
\hline Agent adjectives & Verb & Adjective \\
\hline Masdars & Verb & Noun \\
\hline
\end{tabular}

The lexeme word class determines the internal (morpho-)syntax, i.e. the behaviour of the categorial hybrids in relation to their dependents. This becomes clear when we review the

33 Note that Haspelmath (1996) does not speak of "acquired" but of "derived" word classes. I avoid the term "derived" in order not to convey the impression that the features of the word form were obtained through a derivational operation. As I argue below, the features are obtained through an inflectional operation. 
properties attributed to negative participles. Negative participles contain subject agreement morphology and they have the same argument structure as other verbs in the language. Modifier phrase-internally, their properties are fully verbal. The word form word class (Adjective), on the other hand, shapes the external (morpho-)syntax. Negative participles follow the adjectival inflectional pattern, agree with their head nouns in case and gender and occupy the same syntactic position as other adjectives in the language. Externally, in relation to the head noun, negative participles are adjectival in nature. Accordingly, the internal and external properties of masdars and AAs can be attributed to their lexeme word classes and the word form word classes, respectively. The ability of masdars to govern objects, nominative subjects and adverbial constituents is a feature of the lexeme word class (Verb). The word form word class (Noun) is, among others, reflected in the nominal morphology. AAs can govern direct objects and thus exhibit an internal syntactic property which has to be attributed to the lexeme word class (Verb). The use of AAs in modifier-foregrounding constructions, for instance, is a syntactic property that has to be assigned to the word form word class (Adjective).

Rather than considering the negative participle formation and the masdars formation as instances of word-class changing derivation, both formations can be analysed as word-class changing inflectional processes, because they are semantically regular, general and productive (Haspelmath 1996: 47). From all verbs, with the exception of the defective verbal copula yoo'be (located)' (see section 3.2), negative participles with -umb are created if a negative verbal modifier is needed, i.e. the negative participle formation is relevant to the syntax. Native and borrowed verbs, alike, can be the input of the formation. The outputs of the negative participle formation are devoid of any idiosyncratic interpretations. The negative participles are in a paradigmatic relation to the affirmative, non-hybrid relative verbs. Another argument in favour of an inflectional analysis is the position of the morpheme marking negative participles, -umb. It is located far from clear verbal derivational morphemes (e.g. middle and 
passive morphemes), which are situated closest to the verbal root. Instead it is found between the slot of subject agreement morphemes and the slot of gender/case-agreeing morphemes (see Table 9).

The formation of masdars in Kambaata is equally regular, general and productive. This is, for instance, reflected in the choice of the masdar as the citation form in the Kambaata-Amharic dictionary (1997). Only the defective copula yoo- 'be (located)' is excluded as an input of this formation. ${ }^{34}$ The masdars formation is highly relevant to the syntax and allows a verb to fulfil the same syntactic functions in a clause as primitive members of the word class Noun. The formation of AAs is very general since no evidence has been found so far that the application of the agentive morpheme -aan to verbs is subject to arbitrary limitations; see, e.g., that the morpheme can also be applied to inchoative-stative verbs, e.g. dimb- 'be(come) drunk' $\rightarrow$ dimb-aanchú 'drunkard, someone who has got drunk'. However, the applicability of the -aan-morphemes to nouns (Treis forthcoming a) is very restricted; only approximately ten examples with nominal inputs are attested up until now. The AA formation can be applied productively to borrowed verbs, e.g. the adjective anabbab-aanchú '(someone) who reads,' which is based on the Amharic loan anabbab- 'read'. In contrast to the negative participle formation and the masdars formation, the AA formation is, to a certain extent, semantically irregular. In spite of the name "agent" adjective, not all outputs of the AA formation necessarily denote the semantic agent or syntactic subject of the base verb; due to idiosyncratic reasons, some agent adjectives in fact denote instruments, containers or patients. The AA formation is not relevant to the syntax. Instead of creating agent adjectives in nounmodifying function, speakers have the option of using affirmative relative verbs in the same context, e.g., it-aanchú '(someone) who eats' and it-anó 'who eats'.

\footnotetext{
34 The same gap is reported in the verbal noun ("infinitive") formation in Oromo by Baye Yimam (1988).
} 
The negative participle, masdar and AA formations primarily change the (external) word form word class from Verb to Adjective or Noun. However, the properties attributable to the lexeme word class do not remain unaffected. As Table 16 is intended to show, the acquisition of adjectival or nominal properties, externally, may go along with a certain reduction of verbal features, internally. The internal syntax is best preserved in negative participles, less preserved in masdars and least preserved in AAs. Compared to these categorial hybrids, deverbal nouns, e.g. yaar-an-áta 'cry, shout', which is derived from the verb yaar- 'cry, shout', have lost the syntactic properties of the verbal input completely and are entirely nominalised.

Table 16. Gradient preservation and loss of internal verbal syntax

\begin{tabular}{|l|c|c|c|}
\cline { 2 - 4 } \multicolumn{1}{l|}{} & Nominative subject & Accusative object & Adverbial modifiers \\
\hline Negative participles & + & + & + \\
\hline Masdars & $+/-$ & + & + \\
\hline Agent adjectives & n.a. & $+/-$ & + \\
\hline Deverbal nouns & - & - & - \\
\hline
\end{tabular}

The degree of preservation is here measured according to three parameters: (i) the ability to govern a nominative subject, (ii) the ability to govern an accusative object and (iii) the compatibility with adverbial modifiers (adverbialised adjectives, adverbial clauses).

(i) Negative participles have exclusively nominative subjects. In a clause headed by a masdar, the subject is often marked in the nominative case. It may, however, equally well be encoded by a possessive pronoun. Least frequently, it is expressed by a genitive modifier. On deverbal nouns, the subject of the verb that constituted the input of the derivational process can only be expressed through a possessive suffix or a genitive modifier. The parameter is not applicable to AAs, which mostly refer to the subject of the verb on which they are based. (ii) Negative 
participles and masdars have accusative (and other) objects. AAs can govern accusative objects (like verbs) or genitive modifiers (like nouns). Deverbal nouns can only be modified. (iii) All categorial hybrids are compatible with adverbial modifiers. In contrast, deverbal nouns can only be modified by adjectives.

If inflectional and derivational processes are assumed to form a continuum rather than to be processes that can neatly be told apart (Haspelmath 2002: 70-84), it is possible to locate the formations discussed above on a cline from clearly inflectional to clearly derivational formations. The negative participle formation is clearly inflectional, the masdar formation is

slightly less so, whereas the AA formation has undoubtedly more properties of a derivational process, even though it is not as derivational as the processes responsible for the formation of deverbal nouns such as yaar-an-áta 'cry, shout'.

\section{References}

Azeb Amha, Dimmendaal, Gerrit J. 2006. Converbs in an African perspective. In: Felix Ameka, Alan Dench, and Nick Evans (eds.), Catching grammar. Issues in grammar writing, 393-440. Berlin/New York: Mouton de Gruyter.

Banti, Giorgio 1986. ‘Adjectives’ in East Cushitic. In: Marianne Bechhaus-Gerst and Fritz Serziko (eds.), Cushitic - Omotic: Papers from the International Symposium on Cushitic and Omotic Languages, Cologne, January 6-9, 1986, 203-259. Hamburg: Buske.

Baye Yimam 1988. The subject of infinitives in Oromo. In: Marianne Bechhaus-Gerst and Fritz Serziko (eds.), Cushitic - Omotic: Papers from the International Symposium on Cushitic and Omotic Languages, Cologne, January 6-9, 1986, 607-616. Hamburg: Buske.

Berhanu Mathewos 1986. An analysis of Kambatta proverbs. University of Addis Ababa M.A. thesis. 
Comrie, Bernard 1976. The syntax of action nominal: A cross-language study. Lingua 40(23). 177-201.

Comrie, Bernard 1998. Rethinking the typology of relative clauses. Language Design 1. 5985.

Corbett, Greville G. 1987. The morphology/syntax interface: Evidence from possessive adjectives in Slavonic. Language 63. 299-345.

Crass, Joachim 2005. Das K'abeena. Deskriptive Grammatik einer hochlandostkuschitischen Sprache. Cologne: Köppe.

Haspelmath, Martin 1995. The converb as a cross-linguistically valid category. In: Martin Haspelmath and Ekkehard König (eds.), Converbs in cross-linguistic perspective: Structure and meaning of adverbial verb forms - adverbial participles, gerunds, 1-56. Berlin/New York: Mouton de Gruyter.

Haspelmath, Martin 1996. Word-class changing inflection and morphological theory. In:

Geert Booij and Jaap van Marle (eds.), Yearbook of Morphology 1995, 43-66. Dordrecht: Kluwer.

Haspelmath, Martin 2002. Understanding morphology. London: Arnold.

Hayward, Richard J. 1980. Participles in 'Afar: Evidence for the restructuring of verb suffixes. Bulletin of the School of Oriental and African Studies 43(1). 123-131.

Kambaatissata. Rosaanchi maxaafa. [Kambaata language. School book.] 1989 E.C. Grade 18. Education Bureau, Southern Nations, Nationalities, and Peoples Regional State. Kämbatəñ̃̃a-Amarəñ̃̃a mäzgäbä k'alat [Kambaata-Amharic dictionary] 1997 E.C. Kambaata-Xambaaro Zone Information and Culture Main Department, Southern Nations, Nationalities, and Peoples Regional State.

Keenan, Edward L., Comrie, Bernard 1977. NP accessibility and Universal Grammar. Linguistic Inquiry 8. 63-100.

Leslau, Wolf 1952. Notes on Kambatta of Southern Ethiopia. Africa 22. 348-359. 
Maatewoos Shagana 1992 E.C. Kambaatissa xifati seerrata [The rules of writing Kambaata]. Manuscript, Educational Department of the Kambaata-Alaaba-Xambaaro Zone, Duuraame, Ethiopia.

Malouf, Robert 2006. Mixed categories. In Keith Brown (ed.), Encyclopedia of language and linguistics, Vol. 8, $2^{\text {nd }}$ ed., 175-184. Oxford: Elsevier.

Malchukov, Andrej L. 2006. Constraining nominalization: function/form competition. Linguistics 44(5). 973-1009.

Nikolaeva, Irina 2008. Between nouns and adjectives: A constructional view. Lingua 118. 969-996.

Owens, Jonathan 1985. A Grammar of Harar Oromo (Northeastern Ethiopia). Hamburg: Buske.

Schneider-Blum, Gertrud 2007. A grammar of Alaaba. A Highland East Cushitic language of Ethiopia. Cologne: Köppe.

Spencer, Andrew 2005. Towards a typology of 'mixed categories'. In: C. Orhan Orgun and Peter Sells (eds.), Morphology and the web of grammar. Essays in memory of Steven G. Lapointe, 95-138. Stanford: CLSI Publications.

Spencer, Andrew 2008. Negation in Japanese: A case of morphosyntactic mismatch. Lingua 118. 997-1017.

Treis, Yvonne 2008a. A grammar of Kambaata. Part 1: Phonology, morphology, and nonverbal predication. Cologne: Köppe.

Treis, Yvonne 2008b. Relativization in Kambaata from a typological point of view. In: Zygmunt Frajzyngier and Erin Shay (eds.), Interaction of morphology and syntax: Case studies in Afroasiatic, 161-206. Amsterdam/Philadelphia: Benjamins.

Treis, Yvonne forthcoming a. Polysemous agent nominals in Kambaata (Cushitic). In: HansChristian Luschützky and Franz Rainer (eds.), Polysemy of agent nouns (Special issue of Sprachtypologie und Universalienforschung). 
Treis, Yvonne forthcoming b. Negation in Highland East Cushitic. In: Ghil'ad Zuckermann (ed.), Selected Proceedings of the First Australian Workshop on Afro-Asiatic Linguistics. Leiden: Brill.

Wedekind, Klaus 1990. Generating narratives. Interrelations of knowledge, text variants, and Cushitic focus strategies. Berlin/New York: Mouton de Gruyter. 